\title{
Soil Management and Restoration
}

\author{
Mary I. Williams, Cara L. Farr, Deborah S. Page-Dumroese, \\ Stephanie J. Connolly, and Eunice Padley
}

\section{Introduction}

The destruction of soil is the most fundamental kind of economic loss which the human race can suffer.-The Essential Aldo Leopold: Quotations and Commentaries

Soils sequester carbon (C), store and regulate water, cycle nutrients, regulate temperatures, decompose and filter waste, and support life (Dominati et al. 2010). We depend, and will continue to depend, on these ecosystem services provided by soils, services that are products of interactions between and among abiotic and biotic properties and that are the foundation for self-maintenance in an ecosystem (SER 2004).

But, soil is a limited resource. It takes thousands of years to develop soil, yet it can lose its productive capacity and ecological integrity in a fraction of that time as the result of human activities or natural events (Heneghan et al. 2008; Hillel 2004). The impacts of management actions and natural events can remain on the landscape for decades and longer, leaving land use and historical legacies (Foster et al. 2003; Morris et al. 2014) that can cause profound ecological and economic consequences from lost farm, pasture, or forest productivity. Furthermore, climate shifts and environmental stressors affect soil properties and functions, both

M. I. Williams $(\varangle)$

Nez Perce Tribe Wildlife Division, Lapwai, ID, USA

e-mail: maryw@nezperce.org

C. L. Farr

U.S. Department of Agriculture, Forest Service, Pacific Northwest Region, Portland, OR, USA

D. S. Page-Dumroese

Rocky Mountain Research Station, USDA Forest Service, Moscow, ID, USA

S. J. Connolly

U.S. Department of Agriculture, Forest Service, Northern Research Station, Newtown Square, PA, USA

E. Padley

U.S. Department of Agriculture, Natural Resources Conservation Service, Washington, DC, USA directly and indirectly. Rises in temperature affect decomposition and nutrient cycling, biological populations, and soil hydrologic functions. Flooding is a natural disturbance in riparian and floodplain ecosystems, but flood sizes and frequencies have been altered by human influences through damming and channelizing rivers, draining wetlands, and deforesting floodplains, so that most flooding now often exceeds the natural range of variation.

As natural resources become limited, the value of managing and restoring aboveground and belowground processes becomes more important. Sustainable soil management involves the concepts of using, improving, and restoring the productive capacity and processes of soil (Lal and Stewart 1992), and we can use ecological restoration, which is intimately linked with soil management, to ameliorate degraded and disturbed resources, reverse the trends of soil degradation, and enhance soil properties to regain ecosystem health. Ecological restoration is one of several actions that can ameliorate degraded and disturbed soils, defined as "the process of assisting the recovery of an ecosystem that has been degraded, damaged, or destroyed" (SER 2004). The practice of ecological restoration draws from and integrates many disciplines from agronomy to wildlife management and from engineering to indigenous knowledge.

Concerns about ecosystem services (e.g., food, water, energy, biodiversity conservation) within the context of a changing climate lead to calls for action, research projects, and eventually the development of new management and restoration techniques (Adhikari and Hartemink 2016; McBratney et al. 2014). This chapter begins with a summary of historical forest and rangeland management with respect to soils and is followed by an overview of the shifts in policy and planning and advances in management and restoration. We highlight a few case studies, discuss monitoring, and end with key findings and information needs. 


\section{Context}

Humans are now an order of magnitude more important at moving sediment than the sum of all other natural processes operating on the surface of the planet.-Wilkinson (2005)

\section{Historical Forest Soil Management}

The early history of forests in North America does not include a record of soil impacts, but we can infer some aspects of this from land use and population factors. As Europeans began arriving in North America during the midseventeenth century, total forest area was estimated at 4.14 million $\mathrm{km}^{2}$ (1023 million acres) (Oswalt et al. 2014). Native peoples were soon decimated by disease, and much of their agricultural land reverted to forest naturally (Lewis and Maslin 2015; Mann et al. 1988). The extent of forest cover in what is now the United States, as reconstructed from saw timber inventories, was likely greater from 1650 to 1700 than in any other period (Birdsey et al. 2006). Williams (1989) suggested that forests may have covered "at least four-fifths of the land area east of the Mississippi River." Population increased slowly during the 1700s but jumped from 5.3 million to 76 million people in the 1800s (Fedkiw 1989; MacCleery 2004). To support the increase in population growth, settlers cleared approximately 0.77 million forested $\mathrm{km}^{2}$ for farms and pastures between 1850 and 1910, more area than had been cleared in the previous 250 years (Williams 1989). Following the period of intensive land clearing, the remaining 3.05 million $\mathrm{km}^{2}$ of forest (Oswalt et al. 2014) was largely saved by technological advances; land used to feed draft animals became available for other crops as animal labor was replaced by motorized equipment, and agricultural production per area boomed as a result of plant breeding, irrigation, and fertilizer. In 2012, forested area has increased only slightly to 3.1 million $\mathrm{km}^{2}$ (766 million acres) since 1910 (Oswalt et al. 2014).

Until recently, forest soil management has been characterized primarily by inattention or risk avoidance. Inattention prevailed throughout the 1800s in the absence of regulations, conservation practices, or foresters (Fedkiw 1989; MacCleery 1993); this period of rapid land clearance was also a time of high demand for wood. Land clearing and extraction from remaining forests resulted in an alarming $75 \%$ drawdown of sawtimber stocks between 1800 and 1920 (Birdsey et al. 2006), leading to the first forest conservation policies in the 1930s (MacCleery 1993). Wood was enormously important during the nineteenth century as a fuel source for heat and steam power; it was the only material for building fences up until the mid-1800s (MacCleery 1993); and it also served a significant industrial demand for charcoal (Foster and Aber
2004). After 1850 , lumber production increased quickly as cities were constructed and farmsteads were built in the Great Plains; railroad expansion also used a large proportion of harvested wood (MacCleery 1993).

Timber extraction prior to the Civil War typically focused on removing high-value trees close to waterways, as logs were heavy and difficult to move (Fedkiw 1989). Logging was mainly accomplished by hand-felling trees and skidding the logs with oxen or horse teams. It was a cumbersome process that left most of the forest unaffected, although damage to streambanks and streams was serious, and effects still exist today (Sedell et al. 1991). When railroads came into widespread use in the latter half of the 1800s, destructive logging practices affected larger areas. The most widespread soil damage of that period was caused by fires ignited by sparks from locomotives. Wildfires ripped through logging slash, destroying the organic horizons of soils and leading to postfire erosion, sedimentation, and nutrient loss (Fedkiw 1989; MacCleery 2004). In the western United States, general policies to pile and burn logging slash were adopted to prevent such wildfires (Lyman 1947). However, slash pile burning comes with its own set of short- and long-term consequences to soil properties that long-term research would later identify (reviewed in Rhodes and Fornwalt 2015). In some regions, farming was attempted on unsuitable loggedover soils that eventually reverted to forest.

Soil fertility, as a component of forest site quality, was gradually recognized during the 1920s and 1930s, and research efforts during the following decades focused on matching forest species to site. The use of site index as a rough measure of productive capacity and the construction of yield tables led to the acceptance of the two soil facts: Soils differ widely in their ability to support tree growth and vegetative growth overall; and forest management as well as other types of resource management, such as wildlife management, could be informed and made more productive by a knowledge of soil (Leopold 1933; Wilde 1958).

Forestry operations moved toward mechanization after World War II (WWII) and progressed in stages as technology changed. Simmons wrote in 1949 that the "tractor, the power saw, and the motortruck are becoming commonplace throughout the country, even on small logging jobs." Truck hauling replaced railroads for moving $\log$ to mills, and ground skidders replaced horse teams for dragging logs to pickup points. Road and skid trail layout became important, utilizing engineering techniques to stabilize roadbeds and manage hydrology. This was primarily to maintain longevity of the roads but also served to limit soil movement and loss. With the advent of heavier tractors and specialized logging equipment, soil compaction became a widespread problem. In the 1960s, researchers began to study soil compaction as a factor responsible for decreased forest growth. Insights as to how soil and ecosystem properties may have been changed 
by historical logging, fire, and in some locations subsequent tillage or grazing are gradually becoming available. The recognition that soil porosity was a nationwide forestry concern led to including compaction treatments in the North American Long-Term Soil Productivity (LTSP) study initiated in 1989 (Powers et al. 2005), a research effort which has gathered long-term data on the effects and interactions of compaction and organic matter removal relative to forest growth.

Another forest management issue in the post-WWII era was the realization that removing trees from the forest was akin to harvesting crops and that forest soils, as well as agricultural soils, might be susceptible to nutrient loss. As new laboratory techniques developed, researchers were able to quantify amounts of nutrients in various parts of trees, and tree species, and calculate nutrient budgets that estimated removals in timber harvesting (e.g., Perala and Alban 1982). This research led to guidance on limiting certain types of harvests and on the use of forest fertilization in economically viable situations. One of the first reported forest fertilization successes was at the Charles Lathrop Pack Demonstration Forest in Washington, where researchers documented a positive response using potassium fertilization on red pine (Pinus resinosa) (Heiberg et al. 1964). Fertility concerns, along with improved laboratory equipment and techniques and the advent of soil surveys in forested areas, led to further examination of forest soils and an increased recognition of the importance of organic material in the forest litter layer and upper mineral soil layers. Nutrient changes have been studied in many locations, notably at Hubbard Brook Experimental Forest in New Hampshire, and studies elucidating soil microbial functions have recently provided insights on historical impacts and considerations for future soil management (Jangid et al. 2011).

\section{Historical Rangeland Soil Management}

In the United States, rangelands occupy approximately $35 \%$ of the land area (Reeves and Mitchell 2011); major rangelands include the Great Plains, the Desert Southwest, the Great Basin, and the Intermountain Plains and Valleys. Rangeland is "land on which the indigenous vegetation (climax or natural potential) is predominately grasses, grass-like plants, forbs, or shrubs and is managed as a natural ecosystem. If plants are introduced, they are managed similarly. Rangeland includes natural grasslands, savannas, shrublands, many deserts, tundras, alpine communities, marshes and meadows" (SRM 1998). The majority of rangelands are categorized as drylands, which are lands limited by soil water (Hassan et al. 2005) with soils having, in most cases, low organic matter, low fertility, high accumulations of calcium carbonate, and low nutrient resources, such as available nitrogen $(\mathrm{N})$ and phosphorus (P) (Sharma et al. 1992; Stott and Martin 1989). Despite these limitations, rangelands are expansive and heterogeneous, supporting a diversity of ecosystems that provide ecological, social, and economical services.

Livestock grazing was, and remains to this day, a primary land use of rangelands during the nineteenth and twentieth centuries. Several rangeland research stations, including the Jornada Experimental Range in New Mexico (circa 1912), were developed in the early twentieth century to address and keep pace with the unprecedented and intensive livestock grazing practices in the western United States. Early management was built on assumptions of equilibrium ecology and steady-state management (i.e., the range condition model) (Clements 1916; Dyksterhuis 1949; Sampson 1923), which presumed that livestock grazing controlled plant succession, such that the species composition of plant communities was a linear response to grazing intensity (Briske et al. 2005). For 50 years, the range condition model was the standard protocol and worked moderately well in grasslands dominated by perennial herbaceous forbs and rhizomatous grasses. At the turn of the twentieth century, however, rangeland conditions were considered poor (Gardner 1991), mostly due to improper livestock grazing practices and uninformed management. The inability of the range condition model to account for complex vegetation dynamics such as woody plant encroachment and establishment and spread of nonnative plant species (Westoby et al. 1989), coupled with advances in resilience and state and transition concepts and theories (Briske et al. 2003; Friedel 1991; Holling 1973; Westoby et al. 1989), led to comprehensive reviews of the rangeland profession and management of rangelands. Reviews by the Natural Research Council (1994) and the Society for Range Management (1995) called for and outlined the standardization of monitoring and replacement of the range condition model with a model that could account for multiple states within and across plant communities (i.e., state and transition models) (Briske et al. 2005; Westoby et al. 1989).

\section{Progressive Shifts in Policy and Planning}

The starting point must be the soil, or at least the substrate into which plants must establish and root, for although soil can exist without plants, there are few plants that can exist without soil.Bradshaw (1987)

As we look back on the history of forest and range management, it is apparent that a number of changes in soil management and protection have arisen from new information made possible by advances in research and technology. In recognition of the relationship between aboveground and belowground processes, and with a better understanding of management impacts as well as natural disturbance and 
recovery processes, several approaches and even shifts in policy have been discussed and developed. The soil ecological knowledge (SEK) approach, for example, acknowledges interactions among principal components of the soil systems as well as feedbacks between aboveground and belowground ecosystem processes (Heneghan et al. 2008).

Currently, forest and rangeland soil management includes approaches that protect soils while seeking to avoid and minimize soil damage. This is still a viable and efficient management approach, as rehabilitation and restoration processes are often costly and impractical, constrained by concerns for tree damage and impeded by accessibility, substrate, and terrain. Statutes, regulations, and guidelines at the federal and state levels have been developed to address many aspects of soil resource protection and management. A more proactive approach to the management and rehabilitation of forest soils has gradually been forming, assembling a variety of approaches that use soil properties to guide land management actions as well as taking direct action toward restoring desirable soil properties.

\section{Forest Service Policy}

Limiting the loss of soil productivity has been the focus of soil management on National Forest System (NFS) lands since the 1980s. Under the National Forest Management Act of 1976 (NFMA), all national forests are required to assess the impacts of management actions to ensure that they "will not produce substantial and permanent impairment of the productivity of the land." The NFMA did not define "land productivity," but the USDA Forest Service (hereafter, Forest Service), with guidance from the US Office of General Council, defined it as the capacity of a soil to produce vegetative growth. While land productivity is generally perceived as being broader-including timber, wildlife, watershed, fisheries, and recreation values-soil productivity is essential to the sustained production of all other ecosystem goods and services (Powers et al. 2005). When considering how to monitor land productivity, NFS soil scientists noted the difficulty in detecting a change in productive potential and decided that a change of approximately $15 \%$ would be a detectable threshold. Each NFS region developed soil quality standards to detect changes, and some regions developed management guidance that limited soil disturbance to no more than $15 \%$, or $20 \%$ on an area basis, reasoning that this would protect land productivity.

Forest Service Manual (FSM) Chapter 2550 Soil Management directs soil resource management on NFS lands (USDA FS 2010). The manual was revised in 2010 to provide a greater focus on ecological functions, with an objective of maintaining or improving soil health on NFS lands "to sustain ecological processes and function so that desired ecosystem services are provided in perpetuity." The FSM defines soil quality as "the capacity of a specific kind of soil to function, within natural or managed ecosystem boundaries, to sustain plant and animal productivity, maintain or enhance water and air quality, and support human health and habitation and ecosystem health" (USDA FS 2010). Soil function is any ecological service, role, or task that soil performs. The FSM identifies six soil functions: soil biology (see also Chapter 5), soil hydrology (see also Chapter 3), nutrient cycling (see also Chapter 4), C storage (see also Chapter 1), soil stability and support, and filtering and buffering. In order to provide multiple uses and ecosystem services in perpetuity, these six soil functions need to be active and effectively working.

With the shift of National policy in the 2010s, several NFS regions and forests have adapted soil quality guidance that reflects a greater focus on managing NFS lands to maintain soil ecological functions as a foundation of planning management actions instead of focusing on soil disturbance as a proxy for maintaining productivity. For example, new regional guidance was created in 2012 for the Eastern Region (Region 9). This guidance directs soil scientists to look at the landscape and determine the site-specific soil properties that are at risk for an ecosystem response from management actions (USDA FS 2012). When high risk is found, actions on those soils are mitigated to protect soil quality and ecosystem function. Monitoring of the soil and ecosystem response on these sites is then fed back into the planning process to better inform the next round. The Colville National Forest also took a similar approach in its recent Forest Land and Resource Management Plan (USDA FS 2018). The forest linked important soil properties to the six soil functions identified in the FSM with the goal of maintaining soil function on the landscape.

\section{Use of Ecological Sites and Associated Information}

A more proactive approach to the management and rehabilitation of forest and rangeland soils has gradually been forming, assembling a variety of techniques that use soils and other ecosystem properties to guide management actions, as well as taking direct action toward restoring desirable soil properties. The need for an ecological approach has been recognized for some time. Rowe (1996) stated that, "recognition of land/water ecosystems in a hierarchy of sizes can provide a rational base for the many-scaled problems of protection and careful exploitation in the fields of forestry, agriculture, wildlife and recreation."

The ecological site concept was formed from an integration of previous land classification systems implemented in parts of Canada and Europe during the 1900s (Barnes et al. 1982), along with those previously utilized in the United States, including the Land Systems Inventory (Wertz and Arnold 1972), habitat type classifications pioneered in Finland (Cajander 1926) and widely applied in the 
Northwestern United States (Daubenmire 1968), the US Soil Survey, and the Forest Service's ecological classification system (Bailey 1987; Cleland et al. 1997).

An ecological site is "a conceptual division of the landscape that is defined as a distinctive kind of land based on recurring soil, landform, geological, and climate characteristics that differs from other kinds of land in its ability to produce distinctive kinds and amounts of vegetation and in its ability to respond similarly to management actions and natural disturbances" (Caudle et al. 2013). Ecological site descriptions (ESDs) are linked to soil survey polygons and associated soil and site information, such as vegetation type and structure, disturbance processes, successional states, and rates of change, and these attributes inform management decisions for a variety of uses (Herrick et al. 2006b). Within this standardized methodology, ecological sites are the basic land classification units for documenting soil, site, and biological characteristics for current and potential future conditions (USDA 2003). Ecological site descriptions are being developed for rangelands and forests across the United States and provide a standardized communication and planning tool for land managers to assess site function and develop projects.

State and transition models (STMs) are interpretations linked to ecological sites, modeling the plant communities that typically develop in response to ecosystem drivers (Bestelmeyer et al. 2003). The STM concept is an outgrowth of concepts of ecosystem succession developed over the last century and summarized by Christensen (2014), who stated that, "We now understand that there is no single unique or unifying mechanism for successional change, that successional trajectories are highly varied and rarely deterministic, and that succession has no specific endpoint." State and transition models reflect some of the complexity involved in succession by recognizing typical disturbances and feedback loops, continuous and noncontinuous transitions between states, and alternate stable states for each ecological site. As such, they are a valuable tool in providing a framework for the probable outcomes of management decisions. State and transition models and ecological sites are linked to soil map units in a one-to-many relationship, i.e., an ecological site may occur on multiple soil map units, thus providing spatial information needed for land management planning. However, limitations of polygon-based soil maps (Zhu 2000) must be considered when applying ecological site information.

Agencies including the USDA Natural Resources Conservation Service (USDA NRCS), the Department of Interior's Bureau of Land Management (BLM), and Forest Service have jointly adopted ecological sites and STMs to aid in rangeland management (Bestelmeyer et al. 2017; Pellant et al. 2005). The agencies have developed a systematic rangeland assessment, detailed in the Interagency
Ecological Site Handbook for Rangelands (Caudle et al. 2013), that incorporates STM concepts of ecosystem function specific to ecological sites.

\section{Advances in Management and Restoration}

When exposed to various management practices, soils may lose, retain, or improve their capacity to sustain plant, animal, microbial productivity, health, and vitality while also maintaining balanced hydrologic, $\mathrm{C}$, nutrient cycles and ecosystem functions (Heneghan et al. 2008). Departure from natural ranges of variability due to, for example, loss of organic matter-a key driver of ecosystem functionwarrants restoration. Traditional approaches focus on manipulating a single chemical, physical, or biological factor to improve soil function, such as by establishing plant cover on highly degraded sites to prevent erosion. Improved technology since the 1980s has led to rapid and significant advances in understanding soil processes and interactions with other ecosystem components, such that restoration of structure and function requires the integration of multiple factors (physical, biological, and chemical). For example, an understanding of belowground biology and processes precipitated an emphasis on soil health and the capacity of a soil to function as a vital, living ecosystem that sustains water, air, plants, animals, and humans (Doran and Zeiss 2000). Soil health is a term used to emphasize and convey that soil functions are "mediated by a diversity of living organisms that require management and conservation" (Doran and Zeiss 2000). Soil health is similar to the older term "soil quality" but places a greater emphasis on the biological components of soils and their roles in ecological processes, especially the cycling of organic matter and nutrients.

Increased knowledge of the legacies of past land use also led to recognition of degraded steady states and appropriate adjustments of land management planning objectives. The recognition of soil-mediated legacy effects can be useful for developing realistic and practical restoration goals (see Foster et al. 2003; Morris 2011; Morris et al. 2011, 2013, 2014). Another current focus is the recognition of soils as part of an ecosystem, taking on properties from air, water, plants, and minerals and contributing influences to the system. This approach is evident in planning and modeling applications and in developing indicators for sustainability (Jonsson et al. 2016). Although there is much left to discover, the new knowledge contributes in many ways to our ability to manage and restore soil functions. In the following sections, we discuss soils-based management approaches; changes in forest, fire, and mine reclamation practices; invasive species and soils; and innovative techniques in biochar, seed coatings, and soil transplants. 


\section{Soils-based Management}

Properties observed in soils are a repository of information, referred to as a "soil memory" or "pedomemory" (see references in Nauman et al. 2015a). Biotic and abiotic interactions, such as those between plant communities and soil, over time can develop specific soil properties indicative of site history. Linking soil properties with historical reference plant communities is a foundation for soils-based management frameworks, such as ESDs. Ecological sites and STMs are being used to guide forest and rangeland management and restoration across the United States (Caudle et al. 2013). Mapping soil morphology and ecological sites to estimate historical plant composition has provided guidance for the restoration of historically disturbed red spruce-eastern hemlock (Picea rubens-Tsuga canadensis) forests in the central Appalachian Mountains (Nauman et al. 2015a, b). And in the western United States, mapping ecological sites has been useful in managing and restoring shrub-steppe habitats (Williams et al. 2011, 2016a). In the following sections, we briefly discuss other soils-based management approaches, such as resistance and resilience, soil security, and soil sensitivity.

\section{Application of Resistance and Resilience Concepts}

A framework for assessing the resistance and resilience of sagebrush (Artemisia spp.) and pinyon-juniper (Pinus Juniperus) ecosystems to invasive species and fire threats has been developed for the western United States (Chambers et al. 2014, 2017; Miller et al. 2014). Resistance is "the ability of an area to recover from disturbance, such as wildfire or drought," and resilience is the "ability of an area of land to remain largely unchanged in the face of stress, disturbance, or invasive species" (USDOI 2015) (also see Box 5.1). The concepts are useful to land planning and assessment. Sagebrush communities on cool, moist, more productive sites are more resistant and resilient to drought and species invasions than those at the drier, warmer end of the spectrum (Chambers et al. 2014, 2017; Maestas et al. 2016). While soil differences related to drought resistance are well known in agricultural crops, the concept has not been commonly applied to natural vegetative communities. In the southern Rocky Mountains, particularly in the Four Corners and Upper Rio Grande ecoregions, sagebrush communities are likely to have higher resistance and resilience than those in the Great Basin (Chambers et al. 2014). A substantial portion of the southern Rockies is classified as having moderate to high resistance and resilience due to climate. The monsoonal precipitation pattern also promotes perennial forbs and grasses, leading to higher resistance to invasive species invasion (e.g., Bradford and Laurenroth 2006).
A similar approach is applied to managing pinyon-juniper woodland ecosystems (Miller et al. 2014). Woodlands are long-established, complex ecosystems with a canopy cover of $40 \%$ or less and a well-developed understory (Thomas and Packham 2007). Trees in woodlands are often distributed unevenly, with highly variable spatial patterning. Woodland structure is vital to the continued existence of many organisms such as birds and butterflies, and woodlands also provide ecosystem services such as water quality and quantity. Woodlands, like forests, are valued for their wood products, and tree removal could result in changes in soil nutrients, hydrology, and biodiversity.

\section{Soil Security}

The concept of soil security has emerged in the past decade as a way to communicate and elevate the urgency of maintaining and improving soil resources to support human needs, biological diversity, and ecosystem structure and function (McBratney et al. 2014). Soil security concerns are placed on par with water, food, and energy security, among other factors, that contribute to sustainability. Addressing soil security requires sustaining the capability or long-term productive capacity of soils, as well as maintaining or restoring their condition. A monetary or capital value placed on soils would ensure their consideration in land allocations based on economics. Stewardship, or connectivity of people to the land, is another aspect of achieving soil security, as is public policy and use regulation. As such, soil security includes considerations of soil health and quality but also adds human elements and synthesizes an overall approach within the context of global sustainability. An example of placing value on soils is the assessment of forest land by Oregon's Department of Revenue (ORS 321.805-855). Large tracts of privately owned forestland are classified into productivity groups using information found in the NRCS Soil Survey. Productive soils receive higher productivity classes and are assessed as more valuable for forest management.

\section{Soil Sensitivity}

Several adaptation assessments are using new information derived from soil vulnerability models. Peterman and Ferschweiler (2016) identified soil sensitivity factors that indicate increased vulnerability to drought-related erosion and vegetation loss and predicted changes in vegetation functional groups as a result of climate change. Changing temperature and precipitation regimes directly influence soils, plant productivity and phenology, and ecosystem resilience to invasive species and wildfire. Soil sensitivity is a measure of the ability of a soil to endure or recover from a disturbance. Peterman and Ferschweiler (2016) created vulnerability maps that rank soils according to the presence of vulnerability factors and the potential for change in 
vegetation type under future climate scenarios. Loss of plant cover and productivity due to drought and warm temperatures can lead to increased erosion and loss of important soil properties, such as water holding capacity, stability, organic matter, and nutrients (Breshears et al. 2003; Munson et al. 2011). Vulnerability maps can help managers identify priority areas for restoration and conservation. For example, Ringo and others (2018) developed a geospatial soil drought model for the Pacific Northwest using soil properties and climate information. These data are being used to examine forest resiliency, wildfire risk, and potential management actions to mitigate undesired ecosystem trajectories.

\section{Forest Management}

Forest management has changed in the modern era due to the development of new technologies as well as a better understanding of the ecological impacts of management actions. One major technological change is the mechanization of forest operations, with equipment replacing manpower in harvesting, site preparation, and planting (Silversides 1997). When applied properly, new technology can decrease forestry impacts on soils; for example, the use of low-pressure tires and tracked vehicles produces less compaction, and equipment like the "shovel logger" can reach out as far as $100 \mathrm{~m}$ from a road to fell and move trees. Other technology being used in the United States includes tethered logging systems, which can harvest on slopes up to $80 \%$ in a groundbased system and can provide access to sites with greater limitations.

Compaction is still the most serious issue today on many forest sites because it alters soil porosity, reduces infiltration, and can increase erosion, thereby leading to reduced movement of water, air, and nutrients through the soil; it also impacts microbial populations and can reduce tree growth (Brussard and van Faasen 1994; Bulmer and Simpson 2005; Page-Dumroese et al. 2009; Stone 2002; Thibodeau et al. 2000; von Wilpert and Schäffer 2006; Wang et al. 2005). Depending on soil texture, the depth of compaction, and site resiliency, soil compaction can also alter plant successional pathways and overall productivity. Soil compaction is greatest in roads, trails, and landings but can occur in general harvest areas, depending on the weight of equipment, number of passes, soil wetness, and other factors. The upper few centimeters of organic soil can recover quickly from light to moderate compaction (Adams 1991; Burger et al. 1985; Hatchell and Ralston 1971; Kozlowski 1999). The weight of logging equipment used in harvesting and site preparation activities increase soil bulk density by compressing soil macropores. Typically, about three passes of heavy equipment are needed to cause a significant increase in soil compaction (Williamson and Neilsen 2000). The change in pore space diminishes root access to gas exchange, may result in increasingly anaerobic conditions in the soil, limits moisture infiltration and internal drainage, and can lead to increased soil erosion, water runoff, and reduced rooting volume; these changes result in detrimental impacts on seedling establishment and tree growth (Elliot et al. 1998; Greacen and Sands 1980; Williamson and Neilson 2000).

Compaction in mineral soil is not readily ameliorated, and effects can persist for several decades, depending on the severity of compaction and local conditions (Froehlich and McNabb 1984; Greacen and Sands 1980; Landsberg et al. 2003; NCASI 2004; Page-Dumroese et al. 2006). Degree and duration of compaction and effects on tree growth are dependent on climate, moisture regime, soil texture, structure, and organic matter content (Heninger et al. 1997). While new harvest-related equipment and technologies have helped to reduce the effects of compaction and organic matter removal, season of harvest, number of equipment passes, soil texture, and surface organic matter depth all influence the amount of compaction that occurs during harvesting (Page-Dumroese et al. 2009). A number of methods can be used to decrease significant amounts of compaction, including leaving slash in skid trails, increasing equipment operator skill, being aware of soil conditions and properties, or applying biochar and other soil organic amendments (Han et al. 2009; Heninger et al. 2002; Senyk and Craigdallie 1997). Additional actions to mitigate compaction include tilling or ripping and revegetating compacted areas such as haul roads and landings; this is sometimes done on roads that are being abandoned (Luce 1997; NCASI 2004; Sosa-Pérez and MacDonald 2017).

Landscape topography also plays a large role in the amount of disturbance found in forested landscapes. Steep units had less off-trail compaction than flat units because the equipment is usually confined to trails on steeper slopes. Landings, trails, and corridors are usually the locations for soil compaction, and topsoil displacement usually occurs adjacent to many trails (Page-Dumroese et al. 2009). The presence of roads and landings, especially in steep areas, can lead to erosion and other impacts (Neher et al. 2017; Switalski et al. 2004). Occasionally, logging can trigger slope failures (e.g., landslides, mudflows, debris flows) (Guthrie 2002). Indirect disturbances following forestry operations can include changes in microclimate that affect rates of decomposition and nutrient cycling and alter hydrology (Finér et al. 2016; Sun et al. 2017).

The LTSP study found that leaving the forest floor intact after harvesting is critical on many sites to maintain nutrient cycling and $\mathrm{C}$ inputs (Powers et al. 2005). Organic matter in woody debris, forest floor detritus, and mineral soil is essential for maintaining ecosystem function by supporting soil $\mathrm{C}$ cycling, $\mathrm{N}$ availability, gas exchange, water availability, and biological diversity (Jurgensen et al. 1997; Page-Dumroese 
and Jurgensen 2006). In addition, the buildup of the forest floor may slow the rate of $\mathrm{N}$ mineralization, but using fire as a management tool assists in keeping forest floor $\mathrm{C} / \mathrm{N}$ ratios within ranges more conducive to $\mathrm{N}$ mineralization (DeLuca and Sala 2006).

Surface residues often do not increase soil organic matter content (Spears et al. 2003), but using biochar can increase soil C, which can lead to increased soil aggregates and water holding capacity (Page-Dumroese et al. 2017b). Although slash piling is an economical method to dispose of harvest residues and reduce the volume of unmarketable material, pile burning can have short- and long-term impacts that can alter chemical, physical, and biological soil properties and degrade the productive capacity of soils (Rhoades and Fornwalt 2015). These impacts are variable and depend on soil texture, fuel type and loading, weather conditions, and soil moisture (Dyrness and Youngberg 1957; Frandsen and Ryan 1986; Hardy 1996; Rhodes and Fornwalt 2015; Rhodes et al. 2015). In areas where slash piles are plentiful and burned during the fall when conditions are conducive to large heat pulses into the soil, the need for restoration of severely burned soils is key (Page-Dumroese et al. 2017a). Yet, altering the size of slash piles from large ( $>10 \mathrm{~m}$ diameter) to small ( $<5 \mathrm{~m}$ diameter) and adding woodchip mulch have the potential to reduce the need for rehabilitation of burn scars (Rhoades et al. 2015). Guidelines for leaving slash and organic matter in the Pacific Northwest (Forest Guild 2013) and Rocky Mountain forests (Schnepf et al. 2009) are available.

Repeated harvesting without retaining or replacing sufficient amounts of soil nutrients and organic matter leads to continued concerns for loss of fertility and changes in soil biology, particularly on landforms that are weathered from nutrient-poor geological substrates such as granite or quartzite (Bockheim and Crowley 2002; Doran and Zeiss 2000; Federer et al. 1989; Garrison-Johnston et al. 2003; Grigal 2000; Grigal and Vance 2000; Kimsey et al. 2011). Forest fertilization is used in some areas of the United States, typically at the time of planting and during mid-rotation on plantation sites lacking in soil nutrients (Jokela et al. 2010). Fertilizer applications can be cost-effective depending on site conditions, but economic benefits are difficult to predict over the time period involved in growing a stand of timber (Cornejo-Oviedo et al. 2017; Fox et al. 2007; Miller et al. 2016).

\section{WildFire and Prescribed Fire}

Wildfires are a keystone process of many forest and rangeland systems, especially in the western United States. Wildfires, whether human-caused or natural, impact the litter layer and associated $\mathrm{C}$ and $\mathrm{N}$, alter the environment for soil organisms, and can change the trajectory of forest composition. Fire kills trees and decreases canopy cover, partially or completely burns ground cover, and may form water repellant (hydrophobic) layers in soils, depending on burn severity (DeBano 1981; Madsen et al. 2011). Soil water storage, interception, and evapotranspiration are reduced when vegetation is removed or killed by fire and when organic matter on the soil surface is consumed by fire (Cerda and Robichaud 2009; DeBano et al. 1998; Neary et al. 2005). Fire consumption of ground vegetation and the development of hydrophobic soils increase overland flow erosion and can increase postfire sediment yield (Neary et al. 2005). Some potential secondary effects of severe fires are accelerated erosion and nutrient leaching. However, wildfire can also be beneficial because it reduces hazardous fuel in fire-dominated ecosystems, provides regeneration sites for certain tree and understory species, can increase available water to surviving vegetation, and improves nutrient cycling (Keane and Karau 2010).

As the length of the wildfire season increases due to climate change, the anticipated result is that larger wildfires will occur across the landscape (Abatzoglou and Williams 2016; Jolly et al. 2015). Wildfire concerns have led to an emphasis on accelerated fuel treatments. Busse and others (2014) have summarized the effects of fuel treatments and prescribed fire, noting that in addition to the loss of organic matter, prescribed fire and mechanical thinning operations alter the physical, biological, and chemical properties of the soil. The report encourages land managers to consider the impacts to the soil when planning fuel reduction treatments while acknowledging that these treatments do not make the land completely resistant to wildfire. Similar to the dry western forests and elsewhere, management plans should consider the ecological effects of fuel treatments within a restoration framework to avoid further ecosystem damage.

Many forest stands across the western United States are being thinned to remove fire fuels and reduce the risk of wildfire. Particularly in ponderosa pine (Pinus ponderosa) forests, there have been major changes in ecological structure, composition, and processes because of livestock grazing, fire suppression, logging, road construction, and exotic species introductions (Covington and Moore 1994b; Swetnam et al. 1999). These forests are now more susceptible to large, destructive fires that threaten human and ecological communities (Allen et al. 2002). Restoration in these forests requires the need to balance the heterogeneity of ponderosa pine ecosystems and climate fluctuations while also removing large numbers of trees to make the forests more fire resilient and within the natural range of aboveground and belowground C levels (Jurgensen et al. 1997; Rieman and Clayton 1997).

Concerns over large-scale crown fires can be mitigated with hazardous fuel reductions, but these fuel treatments 
must use ecological principles to limit or prevent further damage (Fulé et al. 2001). Usually, fuel reduction harvesting activities involve cutting and removing small trees with little marketable value (Brown et al. 2004). Residues may be removed and transported to a bioenergy facility (if one is available within a feasible hauling distance), dispersed across a harvest unit by mastication or grinding, or piled and burned (Creech et al. 2012; Jones et al. 2010). Although the impacts of intensive harvests on long-term soil productivity (Powers 2006) are generally known, there is much less known about the impacts of widespread thinning for fire risk reduction. The pattern of disturbance is thought to be different from typical clear-cut and thinning operations (McIver et al. 2003; Miller and Anderson 2002). For example, Landsberg and others (2003) found that the severity of soil compaction on areas thinned for fire risk reduction is dependent on slope.

Wildfire effects and restoration strategies are summarized in Cerda and Robichaud (2009). In the western United States, postfire sediment production may be highly variable, but it can have catastrophic impacts on downstream communities (Moody and Martin 2009). Short-term rehabilitation of burned landscapes tends to be focused on establishing ground cover through mulching or seeding while preventing accelerated erosion. Because of the increased severity and frequency of large wildfires, humans are intervening to assist in postfire ecological recovery efforts (Robichaud et al. 2009). The Forest Service's Burned Area Emergency Response (BAER) program focuses on mitigating unacceptable risks to life, safety, infrastructure, and critical natural and cultural resources on national forests and grasslands. BAER treatments can include erosion control, such as large-scale mulching, to protect municipal watersheds and soil productivity (Beyers 2004; Kruse et al. 2004). The BAER program has been very effective at making timely decisions to protect critical values from short-term damage after fires (e.g., the Hayman Fire in Colorado [Robichaud et al. 2009]). In addition to BAER, long-term postfire restoration focuses on restoring ecosystem function and structure while recovering a level of fire resiliency (Vallejo et al. 2009). Restoration is encouraged in areas where fire is uncommon or fire frequency and severity are outside of the fire regime for the area. Restoration efforts focus on seeding and planting appropriate plant species for the site. In some areas, such as systems managed as wilderness or managed to preserve natural features and ecosystem processes unfettered by humans, it may be desirable to forego restoration efforts after wildland fire. Seeding efforts may inhibit natural regeneration, and soil control measures may lessen the contribution of sediments and associated nutrients in recharging the fertility of streams and lakes located downstream from the burn sites (Christensen et al. 1989).
Restoring fire as an ecosystem process in fire-adapted systems can have beneficial effects (Collins et al. 2009). Over the last century, fire suppression and other management activities have altered the structure and function of forests and rangelands across much of the western United States (Belsky and Blumenthal 1997; Dwire and Kauffman 2003; Hessburg et al. 2005). Forest structure and composition has been most significantly altered due to the lack of fire disturbance. The disruption of the natural fire intervals of the past has resulted in higher stand densities, multilayered stands of mostly one species in some places, and the encroachment of conifers into meadows and grasslands. Dramatically higher stand densities and the development of ladder fuels have increased the risk of uncharacteristically severe wildfire, bark beetle infestations, and in some areas, successional replacement by shade-tolerant competitors. These changes across the landscape increase the probability for disturbances to affect large contiguous areas in uncharacteristic ways. By restoring fire into these ecosystems, generally as part of a management system that includes mechanical thinning and fuel reduction, the forests are restored to lower density stands with higher resiliency to large wildfires and other natural disturbances (Covington and Moore 1994a; Johnstone et al. 2016). Sites that were traditionally savanna ecosystems with widely-spaced trees and grassy understories need more frequent fire to maintain the forest structure (Peterson and Reich 2001). While soil resources are impacted by these management actions, the impacts tend to be less than the results of uncharacteristic large-scale fire disturbances (Hessburg et al. 2005; Johnstone et al. 2016).

\section{Mine Reclamation}

After agriculture and infrastructure development, mining is a major driver of deforestation and land degradation in the Americas (FAO 2016; Hosonuma et al. 2012). Millions of hectares of NFS lands are leased for oil, gas, coal, and geothermal operations. In fiscal year (FY) 2015, \$1.6 billion worth of products were produced by large mines on NFS lands (USDA FS 2017). As many as 39,000 abandoned mines may be located on NFS lands (USDA FS 2017), and the Forest Service works to minimize or eliminate threats to human health and the environment from these mine sites. Under the BLM, the Abandoned Mine Lands (AML) program aims to restore degraded water quality, clean up mine waste and heavy metal, remediate other environmental issues affecting public lands, and mitigate safety concerns on mine sites abandoned prior to January 1, 1981; currently there are roughly 53,000 abandoned mine sites on BLM lands (BLM 2017). In 2011, the US Government Office of Accountability estimated that the cost of reclaiming 161,000 abandoned 
mines on public lands was in the range of \$10-21 billion. These unproductive abandoned areas are often surrounded by productive forests. They are also usually located in rural areas with rugged terrain and limited access. Eight percent of these abandoned lands contain only physical hazards or limitations and no environmental contamination (American Geosciences Institute 2011).

Several federal and state rules and regulations govern the mining process, from approvals, planning, operations, and finally to reclamation and closure. Reclamation is defined as "the process by which derelict or very degraded lands are returned to productivity and by which some measure of biotic function and productivity is restored" (Brown and Lugo 1994). Mine reclamation rules and regulations vary largely by land ownership and type of extraction and can range from weak to stringent. The Forest Service adopted guidance in 2016 to address short- and long-term postmining maintenance and monitoring after reclamation (USDA FS 2017). Surface coal mining, governed by the Surface Mining Control and Reclamation Act of 1977, has very specific guidelines for topsoil salvage and stabilization. State agencies provide further guidance and regulations for reclamation and bond release. For example, shrub standards for reclaimed coal-mined lands in Wyoming require a minimum of one shrub per $\mathrm{m}^{2}$ on lands if land use includes wildlife habitat (Wyoming Department of Environmental Quality 1996).

Early research in mine reclamation focused on soil and water protection, thus single-factor approaches (i.e., manipulating one physical, chemical, or biological factor) were employed to protect soil from erosion. Topsoil salvage and reestablishing an adequate plant community to prevent erosion were emphasized and met with varying results (Schuman 2002; Schuman et al. 1998). There are millions of hectares in the United States, including hundreds of thousands of hectares of Forest Service lands that are reclaimed but not restored. Soil quality is still often highly degraded on reclaimed sites. More modern approaches, transpired from years of reclamation practice and research, call for integrated and innovative approaches that target abiotic and biotic processes so that systems are functional (refer to Heneghan et al. 2008; Herrick et al. 2006b; Hild et al. 2009; King and Hobbs 2006; Lamb et al. 2015; McDonald et al. 2016; Stanturf et al. 2014).

Integration of soil stability, hydrology, nutrient cycling, plant functional traits, species turnover and regeneration, and wildlife interactions will not only help unite research with management but can place reclamation within the context of ecosystem function. Commonly, most projects do not have a level of topsoil or subsoil that is reflective of what was on site prior to the disturbance. Overburden generated from openpit mining can be low in organic matter, soil microorganisms, and plant nutrients such as $\mathrm{N}$ and phosphorus and can lack soil structure and texture that are vital to soil fertility and water-holding capacity (Allen 1989; Feagley 1985). Soil organic matter additions are valuable both for their $\mathrm{C}$ and the microbes contained in the material and provide substantial benefits to the affected site. The erosion and sediment control industry has started to address topsoil limitations by providing products that help to compensate for the loss of topsoil and setback from topsoil storage (see Abdul-Kareem and McRae 1984). One way they are doing this is by adding compost and other organic amendments that address several aspects of soil health, including the microbiological aspect, particularly ectomycorrhizae (Harvey et al. 1979). Reclaiming some areas may require building soil over rocks that have been dredged from local streams (Page-Dumroese et al. 2018). There are several options to initiate the soilbuilding process, but applying a combination of biochar, municipal biosolids, and wood chips offers one way to use local resources to begin to restore site productivity. Operations should weigh the costs and benefits of creating soils or adding soil amendments, as these types of treatments can be expensive.

\section{Soils and Problematic Species}

One of the most troubling developments related to the ease and speed of travel is the movement of nonnative, invasive species among continents. Across North America, these "problematic" insects, pathogens, and plants pose serious threats to forest and rangeland ecosystems because, unlike natural, abiotic disturbances like wind and fire, they are efficient at changing species composition by targeting specific species or outcompeting native species. Insects that cause substantial tree mortality, such as the mountain pine beetle (Dendroctonus ponderosae) that attacks pines (Pinus spp.) (Bentz et al. 2010), the gypsy moth (Lymantria dispar) (Potter and Conkling 2017), and emerald ash borer (EAB) (Agrilus planipennis) (Knight et al. 2012), are powerful drivers of ecosystem and economic change that causes not only shifts in species composition but also changes soil organic matter production, increases coarse woody debris, alters nutrient and water uptake, and changes understory light and temperature (Lovett et al. 2006). In addition, nonnative plants, such as the invasive shrub European buckthorn (Rhamnus cathartica) in the midwestern United States, can alter soil chemical and hydrological properties, leaving legacy effects and management challenges (Heneghan et al. 2006). Similar to postfire landscapes, ecosystems altered by problematic species are subject to flash flooding, soil erosion, and sediment loading.

Management responses to insect and disease impacts are often elusive, but in some cases biocontrols and combinations of treatments can be effective (Havill et al. 2016; Margulies et al. 2017) or sites can be transitioned into other 
vegetation types (D'Amato et al. 2018). Understanding the feedbacks between plant species and soil may help to combat invasion, as exemplified by current research on soil fungal pathogens and cheatgrass (Bromus tectorum) (Meyer et al. 2016). The role of mycorrhizal fungi and other fungal species in combating invasive plant species establishment and spread is also noteworthy (Bellgard et al. 2016; Padamsee et al. 2016). Biochar has been shown to increase the growth of native prairie grasses while decreasing or not affecting invasive perennials (Adams et al. 2013). Some technological advances have had adverse effects on forest soils, and management struggles to adapt. Soil ecological knowledge (SEK) has been applied to prevent or reduce the invasion by exotic species during restoration by adding $\mathrm{C}$ to promote microbial immobilization of available and mineralized $\mathrm{N}$ in abandoned agricultural land (see Heneghan et al. 2006 and references therein), and this has been shown to reduce nonnative plant species cover and colonization (Baer et al. 2003). Carbon addition is a tool to assist community recovery and assembly (nonnative to native). Because biochar is rich in $\mathrm{C}$, it can improve soil quality and increase vegetation growth. In addition, biochar can limit or reduce the growth of invasive species by limiting $\mathrm{N}$ availability (Adams et al. 2013; Page-Dumroese et al. 2017b).

\section{Innovative Approaches}

\section{Biochar}

Land management stresses such as soil compaction, invasive species, disease or insect outbreaks, and wildfire are being exacerbated by a changing climate (Dale et al. 2001). This, coupled with the need to remove encroaching biomass that has little to no value, is increasing operational expenses (Rummer et al. 2005). However, biochar can be one byproduct that brings a high value to traditionally low-value biomass. Biochar is a by-product of pyrolysis of materials such as wood, waste organic materials, and agricultural crop residues at temperatures above $400{ }^{\circ} \mathrm{C}$ under complete or partial elimination of oxygen (Beesley et al. 2011; Lehmann 2007). Because of its porous structure, large surface area, and negatively charged surface (Downie et al. 2009; Liang et al. 2006), biochar has the potential to increase water holding capacity and plant-nutrient retention in many soils (Basso et al. 2013; Gaskin et al. 2007; Kammann et al. 2011; Laird et al. 2010) and is used to amend food crop soils (Blackwell et al. 2009). Biochar retains much of the $C$ of the original biomass, which can offset the use of fossil fuels and can reduce greenhouse gas emissions from soil (Jones et al. 2010). When used as a soil amendment, biochar contributes to increase $\mathrm{C}$ sequestration, enhances the cation exchange capacity, increases $\mathrm{pH}$, and reduces soil bulk density and resistance to gas and water movement (Mukherjee and Lal
2013). All of these changes have been shown to enhance plant growth (Atkinson et al. 2010).

Biochar may be useful for restoring or revitalizing degraded forest, rangeland, and urban soils. It may also provide a method for increasing soil water holding capacity to improve tree health and reduce the incidence of disease and insect attack (Page-Dumroese et al. 2017b). For example, biochar additions of $25 \mathrm{Mg} \mathrm{ha}^{-1}$ resulted in a $10 \%$ increase in available water in August on coarse-textured soil in central Montana (Page-Dumroese et al. 2017b). The biggest benefit of biochar, however, may be in facilitating reforestation of degraded or contaminated sites (Page-Dumroese et al. 2017b). Biochar amendments have the potential to reduce leaching and bioavailability of heavy metals such as copper, zinc, lead, and cadmium (Bakshi et al. 2014; Beesley and Marmioli 2011), mainly as a result of changing the soil pH. On mine sites that contain toxic chemicals from decades of activity, establishing vegetation cover to limit erosion and offsite movement of chemicals was successful when biochar was used (Fellet et al. 2011).

Variability in biochar type, application rate, and mode (e.g., top-dressing, tilled, pellets), as well as environmental setting, can play a role in plant response (Barrow 2012; Lehmann 2007; Solaiman et al. 2012; Van Zwieten et al. 2010). Applying biochar to coarse- to medium-textured, unproductive soils at rates less than 100 metric tons ha ${ }^{-1}$ can improve nutrient supply, water holding capacity, and water availability (Chan et al. 2008; Jeffery et al. 2011). When adding biochar to the soil to improve moisture conditions (i.e., water repellency), it is more effective when mixed into the profile rather than surface applied (Page-Dumroese et al. 2015). Biochar's ability to absorb water and adsorb nutrients is also contingent upon its chemical and physical properties, a function of pyrolysis temperature (e.g., pH and surface area increase with temperature to a point) (Downie et al. 2009; Lehmann 2007). In forest soil applications, for example, biochar produced at $550-650{ }^{\circ} \mathrm{C}$ was better than other temperatures for absorbing water (Kinney et al. 2012). And in a study of different types, in general biochar enhanced water storage capacity of soils, but it varied with feedstock type and pyrolysis temperature (Novak et al. 2012).

Biochar can be designed with characteristics specific to intended objectives, goals, and environmental settings (Novak and Busscher 2013; Novak et al. 2009). Given enough completed studies and data, decision frameworks could help practitioners decide whether or not to use biochar and to determine what type is appropriate based on initial soil properties and other environmental conditions (Beesley et al. 2011). But production costs may outweigh benefits, and it may not be economically feasible for large-scale production and use. Biochar production can cost \$51-\$3747 per ton, a wide range that depends on feedstock type, pyrolysis reaction time (slow or fast), temperature, heat source, and transportation (Meyer 
et al. 2011). Prices for biochar worldwide vary substantially between $\$ 80$ and $\$ 13,480$ US dollars per ton (Jirka and Tomlinson 2013). Until there are verified benefits to using biochar and investments in less expensive technologies to produce biochar, the market prices for biochar will remain uncertain (Campbell et al. 2018). On-site production of biochar is one approach to alleviate high transportation and material acquisition costs, especially in forest systems where a constant supply of wood material left over from harvesting operations is available (Coleman et al. 2010).

\section{Seed Coating Technologies}

Direct seeding in the western United States is a common restoration practice, but germination and seedling emergence can be major barriers to successful revegetation (Chambers 2000; James et al. 2011). Seedbed conditions are highly variable for temperature and moisture (Hardegree et al. 2003), and conditions need to occur that allow seeds to germinate. For some species, the range of temperature and moisture needed for emergence and growth is narrow (Fyfield and Gregory 1989). Seed coatings that facilitate germination and initial growth may be especially useful in situations where nutrients and water are limited (Madsen et al. 2012; Taylor and Harman 1990). Seed coating technologies that use biochar may potentially overcome moisture and temperature limitations that affect native plant germination and growth, especially on arid and semiarid lands, but initial studies show mixed results (Williams et al. 2016b). The cost of seed coatings can be high, which will add to the already expensive price of non-coated native seeds. During 2000-2014, the US Federal Government spent more than $\$ 300$ million on native plant seeds used for revegetating land disturbances; in 2013 alone, the cost exceeded \$20.7 million (U.S. Government 2014).

\section{Soil Transplants}

Many of the aboveground changes in plant species biomass and diversity are linked to the abundance and composition of microbes within the mineral soil (Smith et al. 2003). Management-induced shifts in soil microbial populations that regulate nutrients or decomposition will result in a concomitant change in aboveground production (Bardgett and McAlister 1999). Early examination of the mechanisms in which soil microbes influence plant succession and competition (e.g., Allen 1989; Allen and Allen 1988, 1990) led to research and development of soil transplants and inoculum to steer restoration efforts. In recent times, studies have transplanted soils or soil inoculant to restore late-successional plant communities (Middleton and Bever 2012; Wubs et al. 2016). In related efforts, researchers are also using biological soil crusts (BSC) to expedite restoration of severely stressed sites (Young et al. 2016). Biological soil crusts are communities of organisms (fungi, lichens, bryophytes, cyanobacteria, and algae) that are intimately associated with the mineral soil surface (Bowker 2007; also see Box 5.2). These communities are most often associated with rangeland sites, but they can be found ephemerally, and sometimes abundantly, within most terrestrial ecosystems. Soil crusts can facilitate succession, and therefore, the assisted recovery of these crusts may help speed succession on degraded lands. Plants and BSCs interact to help restore soil quality through soil stability, runoff to infiltration balances, surface albedo, nutrient capture, and available habitat for microbes (Bowker 2007).

\section{Monitoring Restoration Success}

A restored ecosystem should have the following attributes: (1) similar diversity and community structure in comparison to a reference site, (2) presence of indigenous species, (3) presence of functional groups required for long-term stability, (4) capacity of the physical environment to sustain reproduction, (5) normal functioning, (6) integration with the landscape, (7) elimination of potential threats, (8) resilience to natural disturbance, and (9) self-sustainability (SER 2004).

Monitoring is a crucial part of the restoration effort, yet, in practice, only a few attributes, such as plant composition and cover or soil stability, are generally monitored, and usually these attributes are only tracked for a short period of time ( $<5$ years) (Ruiz-Jean and Aide 2005). Studies support that short-term plant community composition monitoring is a necessary but insufficient predictor of long-term success. Examples of long-term monitoring in the western United States show that short-term monitoring alone of plant community composition has detected "false" and "true" failures. In one situation, a project was abandoned after only 4 years and was determined a failure, but decades later the plant community recovered. The lag in plant community response was attributed to soil properties that need more time to recover (i.e., infiltration and nutrient cycling associated with soil organic matter accumulation). The lack of soil organic matter limited the short-term recovery of the system, so it was deemed a reclamation failure (Tongway et al. 2001; Walton 2005; Walton et al. 2001 as cited in Herrick et al. 2006 b). In contrast, many restoration projects deemed successful do not persist because one or more processes are absent (Herrick et al. 2006a; Rango et al. 2005). Integration of ecological indicators that reflect soil and site stability, hydrologic function, and biotic integrity (Pellant et al. 2005) has the potential to help avoid identifying false or true failures in restoration (Herrick et al. 2006b). To understand success in ecosystem restoration, we must understand the linkages of aboveground and belowground changes to biotic interactions, plant community effects, aboveground consumers, and the influences of changing species (Bardgett and Wardle 2010). 
Qualities of good monitoring programs include being well-designed and standardized, and there must be long-term support that allows for continuous monitoring. Effective monitoring programs address clear questions, use consistent and accepted methods to produce high-quality data, include provisions for management and accessibility of samples and data, and integrate monitoring into research programs that foster continued evaluation and utility of data. There are several steps involved in planning what to monitor: (1) define the goals and objectives of the monitoring; (2) compile and summarize the existing information; (3) develop a conceptual model; (4) prioritize and select indicators; (5) develop the sampling design; (6) develop the monitoring protocols; and (7) establish data management, analysis, and reporting procedures (Fancy et al. 2009; Jain et al. 2012). Monitoring can be expensive in terms of personnel, equipment, and time, but relative to the value of resources that restoration activities protect and the policy it informs, monitoring costs very little. Considerable planning before restoration begins will determine monitoring needs and overall success. Herrick and others (2006b) suggest a ten-step iterative approach to monitoring that begins before restoration is initiated, collects short-term data for use in adjusting restoration efforts, and lastly, involves long-term monitoring (see Fig. 8.1). This approach allows for short-term monitoring indicators to also be used for long-term efforts.

Monitoring should be scaled both spatially and temporally to the patterns or processes of the response variable, recognizing that patterns often vary with the scale at which a study is conducted (Levin 1992; Wiens 1989). Because processes and populations vary in time and space, monitoring should be designed and conducted at the scale(s) that encompasses the appropriate variation (Bissonette 1997). Given the variety of factors that might influence a response variable, monitoring should be designed to incorporate as much of the variation resulting from those factors as possible. Spatially, this requires sampling at the appropriate scale to detect a biologically meaningful response should one occur. For example, effects may manifest at the landscape level but be obscured at the stand scale, or vice versa (Bestelmeyer et al. 2006). Determining the spatial scale might be particularly relevant when evaluating treatment effects on population trends of selected species (Ritters et al. 1997) because effects discovered within a restoration project area may not extend to the broader population.

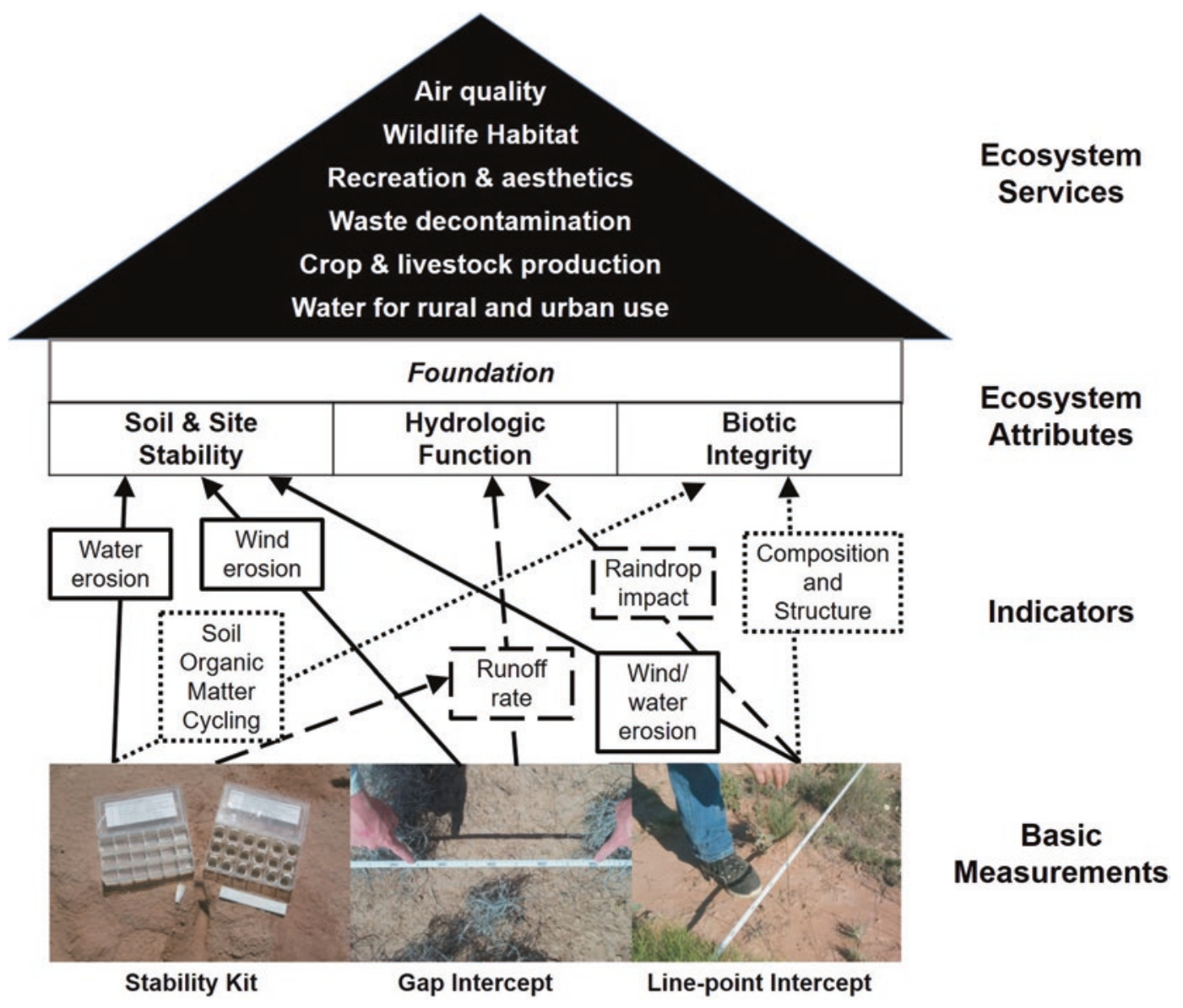

Fig. 8.1 Basic measurements (soil stability, gap intercept, and line-point intercept) used to generate indicators of processes related to ecosystem attributes that serve as the foundation for most ecosystem services and success for restoration projects. (Source: Adapted from Herrick et al. 2006b) 
Temporally, the most obvious solution is to conduct studies over a long enough time to detect change if one is occurring (Morrison 1987; Strayer et al. 1986; Wiens 1984). Long-term studies are appropriate when observing slow processes, rare events, subtle processes, and complex phenomena (Strayer et al. 1986). Examples of slow processes include soil organic matter accumulation, plant succession (Bestelmeyer et al. 2006), invasion by exotic species, and long-term population cycles. Rare events include fire, floods, population irruptions of a food item (e.g., insect epidemics resulting in a numerical response by birds), and various environmental crunches (Morrison 1987). Subtle processes are those that may show little change over a short period but whose effects are greater when viewed within a longer timeframe. Complex phenomena are typically the result of multiple interacting factors. This begs the question: How long should monitoring continue? Strayer and others (1986) suggested that "if it continues for as long as the generation time of the dominant organism or long enough to include examples of the important processes that structure the ecosystem under study... the length of study is measured against the dynamic speed of the system being studied." Clearly, "longterm" depends greatly on the response variable and system under study. For some restoration projects, a single scale may be appropriate, whereas others might require monitoring to be done at multiple scales. Even then, relationships observed at one scale may differ from those observed at another (Wiens 1986). Timescale is important, but research projects, especially graduate work, may not be long enough to capture any changes.

Conducting long-term studies is important for understanding management and restoration impacts on ecosystem processes (Bienes et al. 2016). In the United States, many government agencies have committed to long-term monitoring to identify ecological insights that inform ecosystem management. The LTSP study has been generating soil and vegetation responses to management activities for the past 25 years (Powers et al. 2005). Other long-term monitoring efforts (e.g., Long-Term Ecological Research, Fire-Fire Surrogate study) underscore management and scientist commitment to generating long-term datasets. While some of these long-term efforts were not meant to evaluate ecosystem restoration, their datasets can inform research and management. For example, the newly developed Land Treatment Digital Library (LTDL), a spatially explicit database of land treatments by the BLM, serves as a clearinghouse for over 9000 land treatments (e.g., seeding, prescribed fire, weed control, vegetation/soil manipulations) in the western United States spanning more than 75 years (Pilliod et al. 2017). The LTDL can be used to study or query, for example, vegetation and soil response (Knutson et al. 2014), successional patterns in relation to management, trends in treatment types across time (Copeland et al.
2018), or ability of treatments to meet habitat requirements for key species (Arkle et al. 2014).

\section{Case Studies}

\section{Mower Tract Ecological Restoration: Monongahela National Forest, West Virginia}

The Mower Tract Ecological Restoration project is a landscape-scale restoration effort that combines red spruce restoration, watershed development, and creation of early successional habitat to benefit wildlife (Fig. 8.2) (Barton 2014). In the past, timber removal and coal mining left sites devoid of vegetation with severely compacted soils. These sites were subsequently planted with nonnative plant species such as Norway spruce (Picea abies) and red pine to control erosion and flooding. These activities left the landscape in a state of "arrested succession," where tree growth was stunted and plant recruitment ceased. A suite of restoration activities is now being used to restore habitat and improve water quality; they include soil decompaction, wetland restoration, woody debris loading, and planting of native trees and shrubs. Heavy machinery breaks up compacted soils, tears up grass sod, and knocks down nonnative trees. The dead wood left on the ground creates habitat for plants and animals while new trees are growing. The downed trees also provide perches for birds to naturally spread native seed and encourage natural regeneration. Organic matter from the decaying wood further improves soil conditions and creates a more suitable environment for growth of red spruce and other native plants. Objectives achieved through this project will help conserve and ensure long-term viability of important plants and animal species associated with unique highelevation forest and wetland communities.

\section{Long-Term Soil Productivity Study: North America}

The North American Long-Term Soil Productivity (LTSP) study is novel as it has been collecting data on soil compaction and organic matter removal after clear-cut harvesting for the last 25 years (Powers 2006). The study spans a wide range of forest and climatic regimes. There are several key points: (1) Soils with an already high bulk density are hard to compact more, and (2) coarser-textured soils recover from compaction faster than fine-textured soils (Page-Dumroese et al. 2006). However, soil density recovery was slow, particularly in soils in the frigid temperature regime. These changes in compaction lead to greater short-term (5 years) tree volume growth on coarse-textured soils and less volume growth on fine-textured soil (Gomez et al. 2002). After 

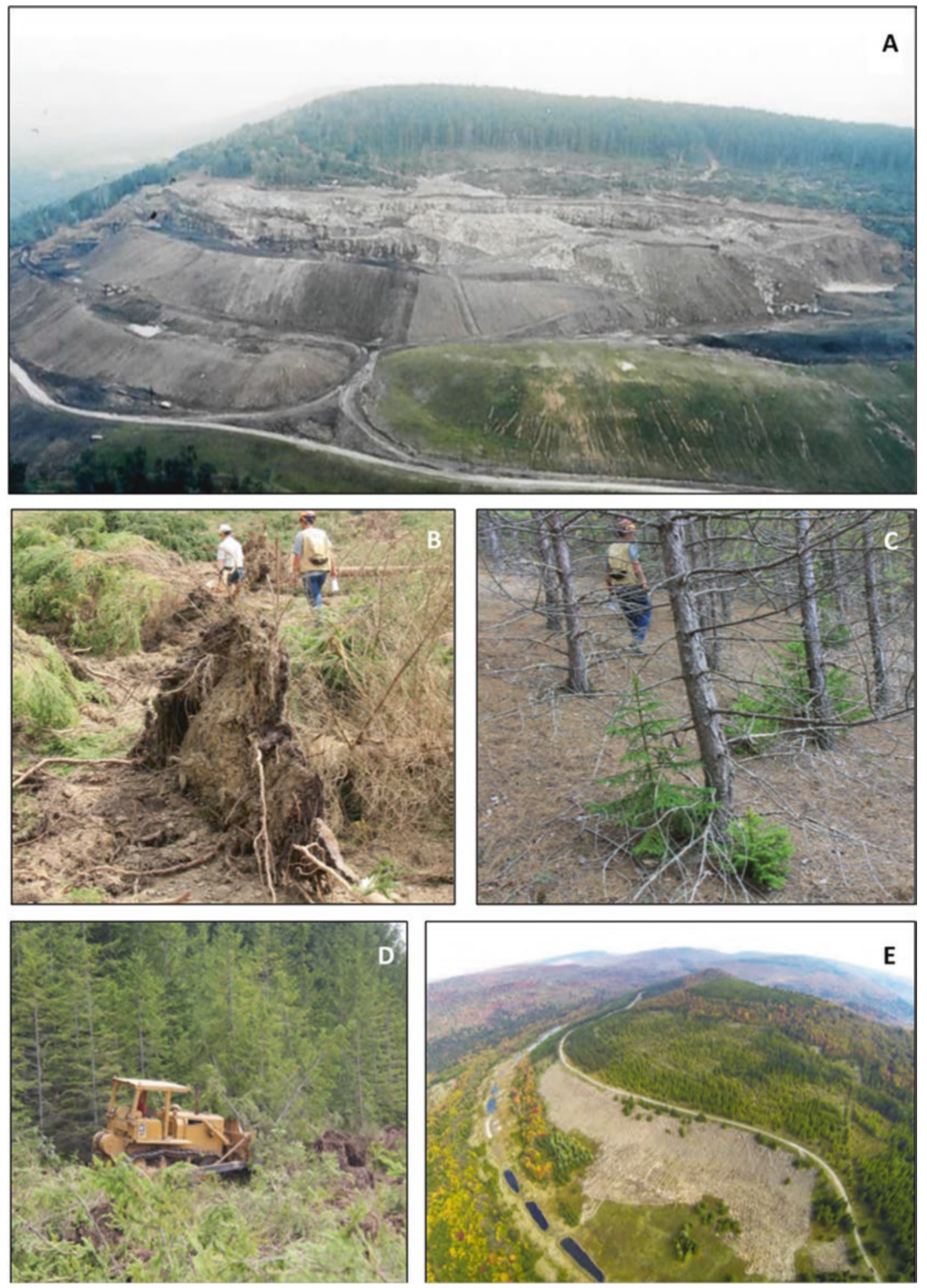

Fig. 8.2 The Mower Tract Ecological Restoration Project. (a) The landscape was mined and logged in the 1980s. (b) Soil compaction involved ripping the soil, removing nonnative trees, and leaving woody debris on site. (e) Aerial view of project (c. 2014). (Photo credit: Chris caused stunted tree growth and low recruitment. (c) Planted nonnative trees were removed to allow growth of native red spruce. (d) Restoration

20 years and for a range of soil textures (sandy loams to clay loams), soil compaction resulted in a $15 \%$ increase in planted tree biomass on the plot-scale basis. This was attributed to
Barton, USDA Forest Service)

increased seedling survival, along with reduced vegetative competition, and was consistent across all the California study sites (Zhang et al. 2017). This same study points to a 
near-complete tolerance of forest biomass growth to compaction and soil organic matter removal; similar to results found in Missouri (Ponder et al. 2012).

Many forest sites are resilient because of their inherent high organic matter levels. However, sites with lower soil organic matter, with deficiencies in one or more soil nutrients, or with fine texture may be at risk for productivity declines as these stands reach crown closure (Zhang et al. 2017). For example, a decade after the complete removal of the surface organic matter, reductions in nutrient availability and soil C concentrations were observed to a depth of $20 \mathrm{~cm}$. Soil C storage was not diminished, likely because of changes in bulk density and the decomposition of residual root systems (Powers et al. 2005).

\section{Soil Matters: Deschutes National Forest, Oregon}

Craigg and others (2015) highlight how using soil mapping along with inherent and dynamic soil quality information can help guide forest management for multiple uses. They discuss the importance and value of regarding soils as the foundational resource in forest planning processes. By appreciating the differing inherent capabilities of the soil, land managers can match the appropriate land uses to the soils that will support those uses. This allows the soils information to set the stage for land management by defining the landscape potential and project objectives through understanding how the soils are able to support long-term ecosystem outcomes. Management actions are then planned based on the appropriate soil types in order to have the highest success rate of meeting the objectives. Interdisciplinary teams work together to strategize how to integrate the objectives and the actions. Projects are then designed and implemented with dynamic soil properties that require protection measures. Upon implementation, ecosystem responses can be monitored to determine if anticipated results are achieved. This information then feeds back to the beginning of the cycle to refine land management objectives. Soil types differ widely in their inherent capacity to perform various ecological functions as well as in their dynamic response to and recovery from disturbances. Incorporating these concepts into planning processes can greatly enhance the quality of forest management decisions.

The Sisters Area Fuels Reduction Project (SAFRP) on the Deschutes National Forest of eastern Oregon serves as a case study for the application and potential benefits of this soilsbased planning tool. Treatments within the planning area had multiple objectives, including improved forest health and resistance to insect epidemics, drought, and serious wildfires in the wildland-urban interface while also providing quality wildlife habitat and other ecosystem services. The Deschutes National Forest soil resource inventory was used to identify three general soil groups within the SAFRP planning area to help assess and match stand-level tree spatial patterns. Each of these soil groups was then paired with the appropriate management objectives in the project design, and treatments were developed to meet desired resource and habitat goals. Post-treatment monitoring has confirmed expectations of desirable stand patterns and vegetation responses where key soil differences were considered. In addition, the project resulted in a successful fuel reduction treatment which aided fire suppression activities during the 2012 Pole Creek Fire.

\section{Key Findings}

- Management and restoration approaches have improved in the last few decades, but innovative developments that inform actions in a timely and cost-effective manner remain priorities.

- Integration of physical, biological, and chemical attributes (a multiple-factor approach) will continue to advance our understanding of soil management and restoration.

- Continuous, targeted, and adaptive monitoring is essential to soil management and restoration, and there is a need for both short- and long-term monitoring.

- Nature is always changing-there is no going back. It takes nearly 500 years to build $2.5 \mathrm{~cm}$ of soil. Therefore, protecting and restoring our current soil stocks is critical.

\section{Key Information Needs}

- What are the boundaries between healthy, at-risk soils and unhealthy soils? It is important to identify thresholds for soil function and structure of soil types and orders.

- How do we determine the best time to take action and what tools are most appropriate?

- How do aboveground and belowground components of the soil interact? A better understanding of how plants, microbes, organic matter, decomposition, and nutrient cycles interact will help improve soil restoration and monitoring efforts.

- How do we design ecological monitoring efforts to detect fluxes and processes at many spatial and temporal scales? Because ecosystems and soils are in a continued state of flux, we must be able to detect these fluxes to ensure ecosystem services are maintained and land is meeting desired ecological conditions. 
Acknowledgments We thank Steve Overby and Steve Williams for reviewing this chapter. We also appreciate input from Mike Brown (Bureau of Land Management), Liam Heneghan (DePaul University), Bart Lawrence (Natural Resources Conservation Service), and Cynthia West (Forest Service) while developing the chapter.

\section{Literature Cited}

Abatzoglou JT, Williams AP (2016) Impact of anthropogenic climate change on wildfire across western US forests. Proc Natl Acad Sci 113(42):11770-11775

Abdul-Kareem AW, McRae SG (1984) The effects on topsoil of longterm storage in stockpiles. Plant Soil 76(1-3):357-363

Adams PW (1991) Soil compaction on woodland properties. In: The woodland workbook. Extension circular 1109. Revised January 1991. Oregon State University Extension Service, Corvallis

Adams MM, Benjamin TJ, Emery NC et al (2013) The effect of biochar on native and invasive prairie plant species. Invasive Plant Sci Manag 6:197-207

Adhikari K, Hartemink AE (2016) Linking soils to ecosystem services: a global review. Geoderma 262:101-111

Allen MF (1989) Mycorrhizae and rehabilitation of disturbed arid soils: processes and practices. Arid Soil Res Rehabil 3:229-241

Allen EB, Allen MF (1988) Facilitation of succession by the nonmycotrophic colonizer Salsola kali (Chenopodiaceae) on a harsh site: effects of mycorrhizal fungi. Am J Bot 75(2):257-266

Allen EB, Allen MF (1990) The mediation of competition by mycorrhizae in successional and patchy environments. In: Grace JB, Tilman D (eds) Perspectives on plant competition. Academic, San Diego, pp 367-389

Allen CD, Savage M, Falk DA et al (2002) Ecological restoration of the southwestern ponderosa pine ecosystems: a broad perspective. Ecol Appl 12:1418-1433

American Geosciences Institute (2011) House Committee on natural resources, subcommittee on energy and mineral resources oversight hearing on mining in America: the administration's use of claim maintenance fees and cleanup of abandoned mine lands. http:// www.americangeosciences.org/policy/house-committee-naturalresources-subcommittee-energy-and-mineral-resources-oversighthearing. Accessed 29 Apr 2018

Arkle RS, Pilliod DS, Hanser SE et al (2014) Quantifying restoration effectiveness using multi-scale habitat models: implications for sage-grouse in the Great Basin. Ecosphere 5(3):1-32

Atkinson CJ, Fitzgerald JD, Hipps NA (2010) Potential mechanisms for achieving agricultural benefits from biochar application to temperate soils: a review. Plant Soil 337(1-2):1-18

Baer SG, Blair JM, Collins SL, Knapp AK (2003) Soil resources regulate productivity and diversity in newly established tallgrass prairie. Ecology 84:724-735

Bailey RG (1987) Suggested hierarchy of criteria for multi-scale ecosystem mapping. Landsc Urban Plan 14:313-319

Bakshi S, He ZL, Harris WG (2014) Biochar amendment affects leaching potential of copper and nutrient release behavior in contaminated sandy soils. J Environ Qual 43:1894-1902

Bardgett RD, McAlister E (1999) The measurement of soil fungal: bacterial biomass ratios as an indicator of ecosystem selfregulation in temperate meadow grasslands. Biol Fertil Soils 29:282-290

Bardgett RD, Wardle DA (2010) Aboveground-belowground linkages: biotic interactions, ecosystem processes, and global change. Oxford University Press, Oxford. 289 p

Barnes BV, Pregitzer KS, Spies TA, Spooner VH (1982) Ecological forest site classification. J For 80:493-498
Barrow CJ (2012) Biochar: potential for countering land degradation and for improving agriculture. Appl Geogr 34:21-28

Barton C (2014) Mower tract ecological restoration: final report 20122014. Monongahela National Forest: Lambert Restoration Project. Green Forests Work and Climate Change Response Framework, 22 $\mathrm{p}$

Basso AS, Miguez FE, Laird DA et al (2013) Assessing potential of biochar for increasing water-holding capacity of sandy soils. GCB Bioenergy 5:132-143

Beesley L, Marmiroli M (2011) The immobilization and retention of soluble arsenic, cadmium, and zinc by biochar. Environ Pollut 159:474-480

Beesley L, Moreno-Jiménez E, Gomez-Eyles JL et al (2011) A review of biochars' potential role in the remediation, revegetation and restoration of contaminated soils. Environ Pollut 159(12):3269-3282

Bellgard SE, Padamsee M, Probst CM et al (2016) Visualizing the early infection of Agathis australis by Phytophthora agathidicida, using microscopy and fluorescent in situ hybridization. For Pathol 46(6):622-631

Belsky AJ, Blumenthal DM (1997) Effects of livestock grazing on stand dynamics and soils in upland forests of the Interior West. Conserv Biol 11(2):315-327

Bentz BJ, Régnière J, Fettig CJ et al (2010) Climate change and bark beetles of the western United States and Canada: direct and indirect effects. Bioscience 60(8):602-613

Bestelmeyer BT, Brown JR, Havstad KM, Alexander R, Chavez G, Herrick JE (2003) Development and use of state-and-transition models for rangelands. J Range Manag 56:114-126

Bestelmeyer BT, Trujillo DA, Tugel AJ, Havstad KM (2006) A multiscale classification of vegetation dynamics in arid lands: what is the right scale for models, monitoring, and restoration? J Arid Environ 65(2):296-318

Bestelmeyer BT, Ash A, Brown JR et al (2017) Chapter 9: State and transition models: theory, applications, and challenges. In: Briske DD (ed) Rangeland systems, Series on environmental management. Springer, New York, pp 303-345

Beyers JL (2004) Post-fire seeding for erosion control: effectiveness and impacts on native plant communities. Conserv Biol 18(4):947-956

Bienes R, Marques MJ, Sastre B, García-Díaz A, Ruiz-Colmenero M (2016) Eleven years after shrub revegetation in semiarid eroded soils: influence in soil properties. Geoderma 273:106-114

Birdsey R, Pregitzer K, Lucier A (2006) Forest carbon management in the United States. J Environ Qual 35(4):1461-1469

Bissonette JA (1997) Scale-sensitive ecological properties: historical context, current meaning. In: Bissonette JA (ed) Wildlife and landscape ecology: effects of pattern and scale. Springer, New York, pp 3-31

Blackwell P, Riethmuller G, Collins M (2009) Biochar application to soil. In: Lehmann J, Joseph S (eds) Biochar for environmental management: science and technology. Earthscan, London, pp 207-226

Bockheim JG, Crowley SE (2002) Ion cycling in hemlock-northern hardwood forests of the Southern Lake Superior region: a preliminary study. J Environ Qual 31(5):1623-1629

Bowker MA (2007) Biological soil crust rehabilitation in theory and practice: an underexploited opportunity. Restor Ecol 15(1):13-23

Bradford JB, Laurenroth WK (2006) Controls over invasion of Bromus tectorum: the importance of climate, soil, disturbance and seed availability. J Veg Sci 17:693-704

Bradshaw AD (1987) The reclamation of derelict land and the ecology of ecosystems. In: Jordan WR, Gilpin ME, Aber JD (eds) Restoration ecology: a synthetic approach to ecological research. Cambridge University Press, Cambridge. 342 p

Breshears DD, Whicker JJ, Johansen MP, Pinder JE III (2003) Wind and water erosion and transport in semi-arid shrubland, grassland and forest ecosystems: quantifying dominance of horizontal and wind driven transport. Earth Surf Process Landf 28:1189-1209 
Briske DD, Fuhlendorf SD, Smeins FE (2003) Vegetation dynamics on rangelands: a critique of the current paradigms. J Appl Ecol 40:601-614

Briske DD, Fuhlendorf SD, Smeins FE (2005) State-and-transition models, thresholds, and rangeland health: a synthesis of ecological concepts and perspectives. Rangel Ecol Manag 58:1-10

Brown S, Lugo AE (1994) Rehabilitation of tropical lands: a key to sustaining development. Restor Ecol 2(2):97-111

Brown RT, Agee JK, Franklin JF (2004) Forest restoration and fire: principles in the context of place. Conserv Biol 18(4):903-912

Brussard L, van Faasen HC (1994) Effects of compaction on soil biota and soil biological processes. In: Soane BD, van Ouwerkerk C (eds) Soil compaction and crop production. Elsevier, Amsterdam, pp 215-235

Bulmer CE, Simpson DG (2005) Soil compaction and water content as factors affecting growth of lodgepole pine seedlings on sandy clay soil. Can J Soil Sci 85:667-679

Burger JA, Perumpral JV, Kreh RE, Torbert JL, Minaei S (1985) Impact of tracked and rubber-tired tractors on a forest soil. Trans Am Soc Agric Eng 28(2):369-373

Busse MD, Moghaddas EEY, Hubbert KD (2014) Fuel reduction practices and their effects on soil quality, General Technical Report PSW-GTR-241. U.S. Department of Agriculture, Forest Service, Pacific Southwest Research Station, Albany. 164 p

Cajander AK (1926) The theory of forest types. Acta Forestalia Fenn 29:1-108

Campbell RM, Anderson NM, Daugaard DE, Naughton HT (2018) Financial viability of biofuel and biochar production from forest biomass in the face of market price volatility and uncertainty. Appl Energy 230:330-343

Caudle D, DiBenedetto J, Karl M et al (2013) Interagency ecological site handbook for rangelands. U.S. Department of the Interior, Bureau of Land Management, Washington, DC. $109 \mathrm{p}$

Cerda A, Robichaud PR (eds) (2009) Fire effects on soils and restoration strategies, vol 5. In: Haigh MJ (series ed) Land reconstruction and management. Science Publishers, CRC Press, Enfield, pp 511-535

Chambers JC (2000) Seed movements and seedling fates in disturbed sagebrush steppe ecosystems: implications for restoration. Ecol Appl 10:1400-1413

Chambers JC, Miller RF, Board DI et al (2014) Resilience and resistance of sagebrush ecosystems: implications for state and transition models and management treatments. Rangel Ecol Manag 67(5):440-454

Chambers JC, Maestas JD, Pyke DA et al (2017) Using resilience and resistance concepts to manage persistent threats to sagebrush ecosystems and greater sage-grouse. Rangel Ecol Manag 70(2):149-164

Chan KY, Van Zwieten L, Meszaros I et al (2008) Using poultry litter biochars as soil amendments. Aust J Soil Res 46:437-444

Christensen NL (2014) An historical perspective on forest succession and its relevance to ecosystem restoration and conservation practice in North America. For Ecol Manag 330:312-322

Christensen NL, Agee JK, Brussard PF et al (1989) Interpreting the Yellowstone fires. Bioscience 39:678-685

Cleland DT, Avers PE, McNab WH et al (1997) National hierarchical framework of ecological units. In: Boyce MS, Haney A (eds) Ecosystem management applications for sustainable forest and wildlife resources. Yale University Press, New Haven, pp 181-200

Clements FE (1916) Plant succession: analysis and development of vegetation. Carnegie Institute, Washington, DC. 512 p

Coleman M, Page-Dumroese D, Archuleta J et al (2010) Can portable pyrolysis units make biomass utilization affordable while using bio-char to enhance soil productivity and sequester carbon? In: Jain TB, Graham RT, Sandquist J (eds) Integrated management of carbon sequestration and biomass utilization opportunities in a changing climate: proceedings of the 2009 national silviculture workshop, General technical report RMRS-P-61. U.S. Department of Agriculture, Forest Service, Rocky Mountain Research Station, Fort Collins, pp 159-168

Collins BM, Miller JD, Thode AE et al (2009) Interactions among wildland fires in a long-established Sierra Nevada natural fire area. Ecosystems 12(1):114-128

Copeland SM, Munson SM, Pilliod DS et al (2018) Long-term trends in restoration and associated land treatments in the southwestern United States. Restor Ecol 26(2):311-322

Cornejo-Oviedo EH, Voelker SL, Mainwaring DB et al (2017) Basal area growth, carbon isotope discrimination, and intrinsic water use efficiency after fertilization of Douglas-fir in the Oregon coast range. For Ecol Manag 389:285-295

Covington WW, Moore MM (1994a) Postsettlement changes in natural fire regimes and forest structure: ecological restoration of oldgrowth ponderosa pine forests. J Sustain For 2(1-2):153-181

Covington WW, Moore MM (1994b) Southwestern ponderosa pine forest structure: changes since Euro-American settlement. J For 92:39-47

Craigg TL, Adams PW, Bennett KA (2015) Soil matters: improving forest landscape planning and management for diverse objectives with soils information and expertise. J For 113(3):343-353

Creech MN, Kirkman LK, Morris LA (2012) Alteration and recovery of slash pile burn sites in the restoration of fire-maintained ecosystems. Restor Ecol 20:505-516

D'Amato A, Palik B, Slesak R et al (2018) Evaluating adaptive management options for black ash forests in the face of emerald ash borer invasion. Forests 9(6):348-365

Dale VH, Joyce LA, McNulty S et al (2001) Climate change and forest disturbances: climate change can affect forests by altering the frequency, intensity, duration, and timing of fire, drought, introduced species, insect and pathogen outbreaks, hurricanes, windstorms, ice storms, or landslides. Am Inst Biol Sci Bull 51(9):723-734

Daubenmire RF (1968) Plant communities: a textbook of plant synecology. Harper and Row, New York. 273 p

DeBano LF (1981) Water repellent soils: a state-of-the-art, General Technical Report PSW-GTR-46. U.S. Department of Agriculture, Forest Service, Pacific Southwest Forest and Range Experiment Station, Berkeley. $20 \mathrm{p}$

DeBano LF, Neary DG, Folliott PF (1998) Fire's effects on ecosystems. Wiley, New York. 335 p

DeLuca TH, Sala A (2006) Frequent fire alters nitrogen transformations in ponderosa pine stands of the inland northwest. Ecology 87(10):2511-2522

Dominati E, Patterson M, Mackay A (2010) A framework for classifying and quantifying the natural capital and ecosystem services of soils. Ecol Econ 69:1858-1868

Doran JW, Zeiss MR (2000) Soil health and sustainability: managing the biotic component of soil quality. Appl Soil Ecol 15:3-11

Downie A, Crosky A, Munroe P (2009) Physical properties of biochar. In: Lehmann J, Joseph S (eds) Biochar for environmental management: science and technology. Earthscan, London, pp 13-32

Dwire KA, Kauffman JB (2003) Fire and riparian ecosystems in landscapes of the western USA. For Ecol Manag 178(1-2):61-74

Dyksterhuis EJ (1949) Condition and management of rangeland based on quantitative ecology. J Range Manag 2:104-105

Dyrness CT, Youngberg CT (1957) The effect of logging and slash burning on soil structure. Soil Sci Soc Am J 21:444-447

Elliot WJ, Page-Dumroese DR, Robichaud PR (1998) The effects of forest management on erosion and soil productivity. In: Lal R (ed) Soil quality and soil erosion. CRC Press, Boca Rattan, pp 195-212

Fancy SG, Gross JE, Carter SL (2009) Monitoring the condition of natural resources in US national parks. Environ Monit Assess 151(1):161-174

Feagley SE (1985) Chemical, physical and mineralogical characteristics of the overburden, Southern Coop series bulletin 294. Arkansas Agricultural Experimental Station, Fayetteville 
Federer CA, Hornbeck JW, Tritton LM et al (1989) Long-term depletion of calcium and other nutrients in eastern US forests. Environ Manag 13(5):593-601

Fedkiw J (1989) The evolving use and management of the nation's forests, grasslands, croplands and related resources: a technical document supporting the 1989 RPA assessment, General technical report GTR-RM-175. U.S. Department of Agriculture Forest Service, Rocky Mountain Forest and Range Experiment Station, Washington, DC. $66 \mathrm{p}$

Fellet G, Marchiol L, Delle Vedove G, Peressotti A (2011) Application of biochar on mine tailings: effects and perspectives for land reclamation. Chemosphere 83:1262-1267

Finér L, Jurgensen M, Palviainen M, Page-Dumroese D (2016) Does clear-cut harvesting accelerate initial wood decomposition? A fiveyear study with standard wood material. For Ecol Manag 372:10-18

Food and Agriculture Organization of the United Nations [FAO] (2016) State of the world's forests 2016: forests and agriculture-land-use challenges and opportunities. FAO, Rome. $107 \mathrm{p}$

Forest Guild Pacific Northwest Biomass Working Group [Forest Guild] (2013) Forest biomass retention and harvesting guidelines for the Pacific Northwest. Forest Guild, Santa Fe. 23 p. Available at https://forestguild.org/publications/research/2013/FG_Biomass_ Guidelines_PNW.pdf. Accessed 22 April 2019

Foster DR, Aber J (2004) Forests in time: ecosystem structure and function as a consequence of 1000 years of change. Synthesis volume of the Harvard forest long term ecological research program. Yale University Press, New Haven

Foster D, Swanson F, Aber J et al (2003) The importance of land-use legacies to ecology and conservation. Bioscience 53(1):77-88

Fox TR, Allen HL, Albaugh TJ et al (2007) Tree nutrition and forest fertilization of pine plantations in the southern United States. South J Appl For 31(1):5-11

Frandsen WH, Ryan KC (1986) Soil moisture reduces below-ground heat flux and soil temperatures under a burning fuel pile. Can J For Res 16:244-248

Friedel MH (1991) Range condition assessment and concepts of thresholds: a viewpoint. J Range Manag 44:422-426

Froehlich HA, McNabb DS (1984) Minimizing soil compaction in Pacific Northwest forests. In: Stone EL (ed) Forest soils and treatment impacts: proceedings of the 6th North American forest soils conference. University of Tennessee, Knoxville, pp 159-192

Fulé PZ, Waltz AEM, Covington WW, Heinlein TA (2001) Measuring forest restoration effectiveness in reducing hazardous fuels. J For 99(11):24-29

Fyfield TP, Gregory PJ (1989) Effects of temperature and water potential on germination, radical elongation, and emergence of mungbean. J Exp Bot 40:667-674

Gardner BD (1991) Rangeland resources: changing uses and productivity. In: Frederick DD, Sedjo RA (eds) America's renewable resources: historical trends and current challenges. Resources for the Future, Washington, DC, pp 123-166

Garrison-Johnston MT, Moore JA, Cook SP, Niehoff GJ (2003) Douglas-fir beetle infestations are associated with certain rock and stand types in the inland northwestern United States. Environ Entomol 32(6):1354-1363

Gaskin JW, Speir A, Morris LM et al (2007) Potential for pyrolysis char to affect soil moisture and nutrient status of a loamy sand soil. Proceedings of the Georgia water resources conference. University of Georgia, Athens, pp 1-3

Gomez A, Powers RF, Singer MJ, Horwath WR (2002) Soil compaction effects on growth of young ponderosa pine following litter removal in California's Sierra Nevada. Soil Sci Soc Am J 66(4):1334-1343

Greacen EL, Sands R (1980) Compaction of forest soils; a review. Aust J Soil Res 18:163-189

Grigal DA (2000) Effects of extensive forest management on soil productivity. For Ecol Manag 128:167-185
Grigal DF, Vance ED (2000) Influence of soil organic matter on forest productivity. N Z J For Sci 30:169-205

Guthrie RH (2002) The effects of logging on frequency and distribution of landslides in three watersheds on Vancouver Island, British Columbia. Geomorphology 43(3-4):273-292

Han S-K, Han S-H, Page-Dumroese DS, Johnson LR (2009) Soil compaction associated with cut-to-length and whole-tree harvesting of a conifer forest. Can J For Res 39:976-989

Hardegree SP, Flerchinger GN, Van Vactor SS (2003) Hydrothermal germination response and the development of probabilistic germination profiles. Ecol Model 167:305-322

Hardy CC (1996) Guidelines for estimating volume, biomass, and smoke production for piled slash, General Technical Report PNWGTR-364. U.S. Department of Agriculture Forest Service, Pacific Northwest Station, Portland. $28 \mathrm{p}$

Harvey AE, Larsen MJ, Jurgensen MF (1979) Comparative distribution of ectomycorrhizae in soils of three western Montana forest habitat types. For Sci 25(2):350-358

Hassan R, Scholes R, Ash N (eds) (2005) Ecosystems and well-being: current state and trends. Island Press, Washington, DC

Hatchell GE, Ralston CW (1971) Natural recovery of surface soils disturbed in logging. Tree Planters Notes 2292:5-9

Havill NP, Shiyake S, Lamb Galloway A et al (2016) Ancient and modern colonization of North America by hemlock woolly adelgid, Adelges tsugae (Hemiptera: Adelgidae), an invasive insect from East Asia. Mol Ecol 25(9):2065-2080

Heiberg SO, Madgwick HAI, Leaf AL (1964) Some long-time effects of fertilization on red pine plantations. For Sci 10(1):17-23

Heneghan L, Fatemi F, Umek L et al (2006) The invasive shrub European buckthorn (Rhamnus cathartica, L.) alters soil properties in midwestern US woodlands. Appl Soil Ecol 32(1):142-148

Heneghan L, Miller SP, Baer S et al (2008) Integrating soil ecological knowledge into restoration management. Restor Ecol 16(4):608-617

Heninger RL, Terry T, Dobkowski A, Scott W (1997) Managing for sustainable site productivity: Weyerhaeuser's forestry perspective. Biomass Bioenergy 13(4/5):255-267

Heninger R, Scott W, Dobkowski A et al (2002) Soil disturbance and 10 -year growth response of coast Douglas-fir on non-tilled and tilled skid roads in the Oregon cascades. Can J For Res 32:233-246

Herrick JE, Havstad KM, Rango A (2006a) Remediation research in the Jornada Basin: past and future. In: Havstad KM, Huenneke LF, Schlesinger WH (eds) Structure and function of a Chihuahuan Desert ecosystem: the Jornada Basin long-term ecological research site. Oxford University Press, New York, pp 278-304

Herrick JE, Schuman GE, Rango A (2006b) Monitoring ecological processes for restoration projects. J Nat Conserv 14:161-171

Hessburg PF, Agee JK, Franklin JF (2005) Dry forests and wildland fires of the inland Northwest USA: contrasting the landscape ecology of the pre-settlement and modern eras. For Ecol Manag 211(1-2):117-139

Hild A, Shaw N, Paige G, Williams M (2009) Integrated reclamation: approaching ecological function. In: Barnhisel RI (ed) Revitalizing the environment: proven solutions and innovative approaches. National Meeting of the American Society of Mining and Reclamation, Billings, pp 578-596

Hillel D (2004) Introduction to environmental soil physics. Elsevier Academic Press, San Diego. 494 p

Holling CS (1973) Resilience and stability of ecological systems. Annu Rev Ecol Syst 4:1-23

Hosonuma N, Herold M, De Sy V et al (2012) An assessment of deforestation and forest degradation drivers in developing countries. Environ Res Lett 7(4):044009

Jain TB, Pilliod DS, Graham RT et al (2012) Index for characterizing post-fire soil environments in temperate coniferous forests. Forests 3(3):455-466 
James JJ, Svejcar TJ, Rinella MJ (2011) Demographic processes limiting seedling recruitment in aridland restoration. J Appl Ecol 48(4):961-969

Jangid K, Williams MA, Franzluebbers AJ, Schmidt TM, Coleman DC, Whitman WB (2011) Land-use history has a stronger impact on soil microbial community composition than aboveground vegetation and soil properties. Soil Biol Biochem 43(10):2184-2193

Jeffery S, Verheijen FG, van der Velde M, Bastos AC (2011) A quantitative review of the effects of biochar application to soils on crop productivity using meta-analysis. Agric Ecosyst Environ 144(1):175-187

Jirka S, Tomlinson T (2013) State of the biochar industry: a survey of commercial activity in the biochar field. [Publisher unknown], [Place of publication unknown]. Report of the International Biochar Initiative. $61 \mathrm{p}$

Johnstone JF, Allen CD, Franklin JF et al (2016) Changing disturbance regimes, ecological memory, and forest resilience. Front Ecol Environ 14(7):369-378

Jokela EJ, Martin TA, Vogel JG (2010) Twenty-five years of intensive forest management with southern pines: important lessons learned. J For 108(7):338-347

Jolly WM, Cochrane MA, Freeborn PH et al (2015) Climate-induced variations in global wildfire danger from 1979 to 2013. Nat Commun 6:7537

Jones G, Loeffler D, Calkin D, Chung W (2010) Forest treatment residues for thermal energy compared with disposal by on-site burning: emissions and energy return. Biomass Bioenergy 34(5):737-746

Jónsson JOG, Davíðsdóttir B, Jónsdóttirb EM et al (2016) Soil indicators for sustainable development: a transdisciplinary approach for indicator development using expert stakeholders. Agric Ecosyst Environ 232:179-189

Jurgensen MF, Harvey AE, Graham RT, Page-Dumroese DS, Tonn JR, Larsen MJ, Jain TB (1997) Impacts of timber harvesting on soil organic matter, nitrogen, productivity, and health of inland northwest forests. For Sci 43(2):234-251

Kammann CI, Linsel S, Gößling JW, Koyro H-W (2011) Influence of biochar on drought tolerance of Chenopodium quinoa Willd and on soil-plant relations. Plant Soil 345(1-2):195-210

Keane RE, Karau E (2010) Evaluating the ecological benefits of wildfire by integrating fire and ecosystem simulation models. Ecol Model 221(8):1162-1172

Kimsey MJ, Garrison-Johnston MT, Johnson L (2011) Characterization of volcanic ash-influenced forest soils across a geoclimatic sequence. Soil Sci Soc Am J 75(1):267-279

King EG, Hobbs RJ (2006) Identifying linkages among conceptual models of ecosystem degradation and restoration: towards an integrative framework. Restor Ecol 14(3):369-378

Kinney TJ, Masiello CA, Dugan B et al (2012) Hydrologic properties of biochars produced at different temperatures. Biomass Bioenergy 41:34-43

Knight KS, Brown JP, Long RP (2012) Factors affecting the survival of ash (Fraxinus spp.) trees infested by emerald ash borer (Agrilus planipennis). Biol Invasions 15(2):371-383

Knutson KC, Pyke DA, Wirth TA et al (2014) Long-term effects of seeding after wildfire on vegetation in Great Basin shrubland ecosystems. J Appl Ecol 51(5):1414-1424

Kozlowski TT (1999) Soil compaction and growth of woody plants. Scand J For Res 14(6):596-619

Kruse R, Bend E, Bierzychudek P (2004) Native plant regeneration and introduction of nonnatives following post-fire rehabilitation with straw mulch and barley seeding. For Ecol Manag 196(2-3):299-310

Laird DA, Fleming P, Davis DD et al (2010) Impact of biochar amendments on the quality of a typical Midwestern agricultural soil Geoderma 158(3-4):443-449

Lal R, Stewart BA (1992) Need for land restoration. In: Soil restoration. Springer, New York, pp 1-11
Lamb D, Erskine PD, Fletcher A (2015) Widening gap between expectations and practice in Australian minesite rehabilitation. Ecol Manag Restor 16(3):186-195

Landsberg JD, Miller RE, Anderson HW, Tepp JS (2003) Bulk density and soil resistance to penetration as affected by commercial thinning operations in northeastern Washington, Research Paper PNW-RP-551. U.S. Department of Agriculture, Forest Service, Pacific Northwest Research Station, Portland. $35 \mathrm{p}$

Lehmann J (2007) Bio-energy in the black. Front Ecol Environ 5(7):381-387

Leopold A (1933) Game management. University of Wisconsin Press, $481 \mathrm{p}$

Levin SA (1992) The problem of pattern and scale in ecology: the Robert H. MacArthur award lecture. Ecology 73(6):1943-1967

Lewis SL, Maslin MA (2015) Defining the anthropocene. Nature 519(7542):171-180

Liang B, Lehmann J, Solomon D et al (2006) Black carbon increases cation exchange capacity in soils. Soil Sci Soc Am J 70(5):1719-1730

Lovett GM, Canham CD, Arthur MA et al (2006) Forest ecosystem responses to exotic pests and pathogens in eastern North America. Bioscience 56(5):395-405

Luce CH (1997) Effectiveness of road ripping in restoring infiltration capacity of forest roads. Restor Ecol 5(3):265-270

Lyman CK (1947) Slash disposal as related to fire control on the national forests of western Montana and northern Idaho. J For 45:259-262

MacCleery DW (1993) American forests: a history of resiliency and recovery, FS-540. U.S. Department of Agriculture, Forest Service; Forest History Society, Durham

MacCleery DW (2004) The historical record for the pathway hypothesis. In: Fedkiw J, MacCleery DW, Sample VA (eds) Pathway to sustainability: defining the bounds on forest management. Forest History Society, Durham, pp 19-42

Madsen MD, Zvirzdin DL, Petersen SL et al (2011) Soil water repellency within a burned piñon-juniper woodland: spatial distribution, severity, and ecohydrologic implications. Soil Sci Soc Am J 75(4): 1543

Madsen MD, Kostka SJ, Inouye AL, Zvirzdin DL (2012) Postfire restoration of soil hydrology and wildland vegetation using surfactant seed coating technology. Rangel Ecol Manag 65(3):253-259

Maestas JD, Campbell SB, Chambers JC et al (2016) Tapping soil survey information for rapid assessment of sagebrush ecosystem resilience and resistance. Rangelands 38(3):120-128

Mann LK, Johnson DW, West DC et al (1988) Effects of whole-tree and stem-only clearcutting on postharvest hydrologic losses, nutrient capital, and regrowth. For Sci 34(2):412-428

Margulies E, Bauer L, Ibáñez I (2017) Buying time: preliminary assessment of biocontrol in the recovery of native forest vegetation in the aftermath of the invasive emerald ash borer. Forests 8(10):369-383

McBratney A, Field DJ, Koch A (2014) The dimensions of soil security. Geoderma 213:203-213

McDonald T, Gann GD, Jonson J, Dixon KW (2016) International standards for the practice of ecological restoration-including principles and key concepts. Society for Ecological Restoration, Washington, DC

McIver JD, Adams PW, Doyal JA et al (2003) Environmental effects and economics of mechanized logging for fuel reduction in northeastern Oregon mixed-conifer stands. West J Appl For 18(4):238-249

Meyer S, Glaser B, Quicker P (2011) Technical, economical, and climate-related aspects of biochar production technologies: a literature review. Environ Sci Technol 45:9473-9483

Meyer SE, Beckstead J, Pearce J (2016) Community ecology of fungal pathogens on Bromus tectorum. In: Exotic brome-grasses in arid and semiarid ecosystems of the western US. Springer International Publishing, Cham, pp 193-223 
Middleton EL, Bever JD (2012) Inoculation with a native soil community advances succession in a grassland restoration. Restor Ecol 20(2):218-226

Miller D, Anderson H (2002) Soil compaction: concerns, claims, and evidence. In: Baumgartner D, Johnson L, DePuit E, comps. Proceedings on small diameter timber: resource management, manufacturing, and markets. Bulletin MISC0509. Washington State University Cooperative, Spokane, pp 16-18

Miller RF, Chambers JC, Pellant M (2014) A field guide for selecting the most appropriate treatment in sagebrush and piñon-juniper ecosystems in the Great Basin: evaluating resilience to disturbance and resistance to invasive annual grasses, and predicting vegetation response, General Technical Report RMRS-GTR-322-rev. U.S. Department of Agriculture, Forest Service, Rocky Mountain Research Station, Fort Collins. $68 \mathrm{p}$

Miller RF, Harrington TB, Anderson HW (2016) Stand dynamics of Douglas-fir 20 years after precommercial thinning and nitrogen fertilization on a poor-quality site, Research Paper PNW-RP-606. U.S. Department of Agriculture Forest Service, Pacific Northwest Research Station, Portland. $66 \mathrm{p}$

Moody JA, Martin DA (2009) Synthesis of sediment yields after wildland fire in different rainfall regimes in the western United States. Int J Wildland Fire 18(1):96-115

Morris LR (2011) Land-use legacies of cultivation in shrublands: ghosts in the ecosystem. Nat Resour Environ Issues 17(1):1-6

Morris LR, Monaco TA, Sheley RL (2011) Land-use legacies and vegetation recovery 90 years after cultivation in Great Basin sagebrush ecosystems. Rangel Ecol Manag 64(5):488-497

Morris LR, Monaco TA, Leger E et al (2013) Cultivation legacies alter soil nutrients and differentially affect plant species performance nearly a century after abandonment. Plant Ecol 214(6):831-844

Morris LR, Monaco TA, Sheley RL (2014) Impact of cultivation legacies on rehabilitation seedings and native species reestablishment in Great Basin shrublands. Rangel Ecol Manag 67(3):285-291

Morrison ML (1987) The design and importance of long-term ecological studies: analysis of vertebrates in the Inyo-White Mountains, California. In: Szaro RC, Severson KE, Patton DR, tech. coord. Management of amphibians, reptiles, and small mammals in North America. General Technical Report RM-GTR-166. U.S. Department of Agriculture, Forest Service, Rocky Mountain Forest and Range Experiment Station, Fort Collins, pp 267-275

Mukherjee A, Lal R (2013) Biochar impacts on soil physical properties and greenhouse gas emissions. Agronomy 3(2):313-339

Munson SM, Belnap J, Okin G (2011) Responses of wind erosion to climate induced vegetation changes on the Colorado plateau. Proc Natl Acad Sci 108:3854-3859

National Council for Air and Stream Improvement, Inc. [NCASI] (2004) Effects of heavy equipment on physical properties of soils and on long-term productivity: a review of literature and current research, Technical bulletin 887. National Council for Air and Stream Improvement, Inc., Research Triangle Park

National Research Council (1994) Rangeland health: new methods to classify, inventory, and monitor rangelands. National Academies Press, Washington, DC. $180 \mathrm{p}$

Nauman TW, Thompson JA, Teets SJ, Dilliplane TA, Bell JW, Connolly SJ, Liebermann HJ, Yoast KM (2015a) Ghosts of the forest: mapping pedomemory to guide forest restoration. Geoderma 247-248:51-64

Nauman TW, Thompson JA, Teets J et al (2015b) Pedoecological modeling to guide forest restoration using ecological site descriptions. Soil Sci Soc Am J 79(5):1406-1419

Neary DG, Ryan KC, DeBano LF eds (2005) (revised 2008) Wildland fire in ecosystems: effects of fire on soils and water. General technical report RMRS-GTR-42-vol. 4. U.S. Department of Agriculture, Forest Service, Rocky Mountain Research Station, Ogden
Neher DA, Williams KM, Lovell ST (2017) Environmental indicators reflective of road design in a forested landscape. Ecosphere 8(3):01734

Novak JM, Busscher WJ (2013) Selection and use of designer biochars to improve characteristics of southeastern USA coastal plain degraded soils. In: Advanced biofuels and bioproducts. Springer, New York, pp 69-96

Novak JM, Busscher WJ, Laird DL et al (2009) Impact of biochar amendment on fertility of a southeastern coastal plain soil. Soil Sci 174(2):105-112

Novak JM, Busscher WJ, Watts DW et al (2012) Biochars impact on soil moisture storage in an Ultisol and two Aridisols. Soil Sci 177(5):310-320

Oswalt SN, Smith WB, Miles PD, Pugh SA (2014) Forest resources of the United States, 2012: a technical document supporting the forest service 2015 update of the RPA assessment, General Technical Report WO-GTR-91. U.S. Department of Agriculture, Forest Service, Washington Office, Washington, DC. 218 p

Padamsee M, Johansen RB, Stuckey SA et al (2016) The arbuscular mycorrhizal fungi colonising roots and root nodules of New Zealand kauri Agathis australis. Fungal Biol 120:807-817

Page-Dumroese DS, Jurgensen MF (2006) Soil carbon and nitrogen pools in mid- to late-successional forest stands of the northwestern USA: potential impact of fire. Can J For Res 36(9):2270-2284

Page-Dumroese DS, Jurgensen MF, Tiarks AE et al (2006) Soil physical property changes at the North American long-term soil productivity study sites: 1 and 5 years after compaction. Can J For Res 36(3):551-564

Page-Dumroese DS, Jurgensen MF, Terry T (2009) Maintaining soil productivity during forest or biomass-to-energy thinning harvests in the western United States. West J Appl For 25(1):5-11

Page-Dumroese DS, Robichaud PR, Brown RE, Tirocke JM (2015) Water repellency of two forest soils after biochar addition. Trans Am Soc Agric Biol Eng 58(2):335-342

Page-Dumroese DS, Busse MD, Archuleta JG et al (2017a) Methods to reduce forest residue volume after timber harvesting and produce black carbon. Scientifica 2017:2745764. 8 p

Page-Dumroese DS, Coleman MD, Thomas SC (2017b) Opportunities and uses of biochar on forest sites in North America. In: Bruckman VJ, Varol EA, Uzun BB, Liu J (eds) Biochar: a regional supply chain approach in view of climate change mitigation. Cambridge University Press, Cambridge, pp 315-334

Page-Dumroese DS, Ott MR, Strawn DG, Tirocke JM (2018) Using organic amendments to restore soil physical and chemical properties of a mine site in northeastern, Oregon, USA. Appl Eng Agric 34:43-55

Pellant M, Shaver P, Pyke DA, Herrick JE (2005) Interpreting indicators of rangeland health, version 4, Technical reference 1734-6. U.S. Department of the Interior, Bureau of Land Management, National Science and Technology Center, Denver. $122 \mathrm{p}$

Perala DA, Alban DH (1982) Biomass, nutrient distribution and litterfall in Populus, Pinus and Picea stands on two different soils in Minnesota. Plant Soil 64(2):177-192

Peterman W, Ferschweiler K (2016) A case study for evaluating potential soil sensitivity in arid land systems. Integr Environ Assess Manag 12(2):388-396

Peterson DW, Reich PB (2001) Prescribed fire in oak savanna: fire frequency effects on stand structure and dynamics. Ecol Appl 11(3):914-927

Pilliod DS, Welty JL, Toevs GR (2017) Seventy-five years of vegetation treatments on public rangelands in the great basin of North America. Rangelands 39(1):1-9

Ponder F Jr, Fleming RL, Berch S et al (2012) Effects of organic matter removal, soil compaction, and vegetation control on 10th year biomass and foliar nutrition: LTSP continent-wide comparisons. For Ecol Manag 278:35-54 
Potter KM, Conkling BL (eds) (2017) Forest health monitoring: national status, trends, and analysis 2016, General Technical Report SRS-GTR-222. U.S. Department of Agriculture, Forest Service, Southern Research Station, Asheville. $195 \mathrm{p}$

Powers RF (2006) LTSP: genesis of the concept and principles behind the program. Can J For Res 36:519-529

Powers RF, Scott DA, Sanchez FG et al (2005) The north American long-term soil productivity experiment: findings from the first decade of research. For Ecol Manag 220:31-50

Rango A, Huenneke L, Buonopane M et al (2005) Using historic data to assess effectiveness of shrub removal in southern New Mexico. J Arid Environ 62:75-91

Reeves MC, Mitchell JE (2011) Extent of coterminous U.S. rangelands: quantifying implications of differing agency perspectives. Rangel Ecol Manag 64:585-597

Rhoades CC, Fornwalt PJ (2015) Pile burning creates a fifty-year legacy of openings in regenerating lodgepole pine forests in Colorado. For Ecol Manag 226:203-209

Rhoades CC, Fornwalt PJ, Paschke MW et al (2015) Recovery of small pile burn scars in conifer forests of the Colorado front range. For Ecol Manag 347:180-187

Rieman B, Clayton J (1997) Wildlife and native fish: issues of forest health of sensitive species. Fisheries 22(11):6-15

Ringo C, Bennett K, Noller J et al (2018) Modeling droughty soils at regional scales in Pacific Northwest Forests, USA. For Ecol Manag 424:121-135

Ritters KH, O’Neill RV, Jones KB (1997) Assessing habitat suitability at multiple scales: a landscape-level approach. Biol Conserv 81:191-202

Robichaud PR, Lewis SA, Brown RE, Ashmun LE (2009) Emergency post-fire rehabilitation treatment effects on burned area ecology and long-term restoration. Fire Ecol 5(1):115-128

Rowe JS (1996) Land classification and ecosystem classification. Environ Monit Assess 39(1-3):11-20

Ruiz-Jean MC, Aide TM (2005) Restoration success: how is it being measured? Restor Ecol 13(3):569-577

Rummer B, Prestemon J, May D et al (2005) A strategic assessment of forest biomass and fuel reduction treatments in western states, General Technical Report RMRS-GTR-149. U.S. Department of Agriculture, Forest Service, Rocky Mountain Research Station, Fort Collins. $17 \mathrm{p}$

Sampson AW (1923) Range and pasture management. Wiley, New York

Schnepf C, Graham RT, Kegley S, Jain TB (2009) Managing organic debris for forest health, Pacific northwest extension publication PNW 609. Univeristy of Idaho, Moscow, p 60

Schuman GE (2002) Mined land reclamation in the northern Great Plains: have we been successful? In: Proceedings 19th annual meeting, American Society of Mining and Reclamation. American Society of Mining and Reclamation, Lexington, pp 9-13

Schuman GE, Booth DT, Cockrell JR (1998) Cultural methods for establishing Wyoming big sagebrush on mined lands. J Range Manag 51:223-230

Sedell JR, Leone FN, Duval WS (1991) Water transportation and storage of logs. In: Meehan WR (ed) Influences of forest and rangeland management on salmonid fishes and their habitats, Special publication 19. American Fisheries Society, Bethesda, pp 325-368

Senyk JP, Craigdallie D (1997) Effects of harvest methods on soil properties and forest productivity in interior British Columbia, Informational report BC-X-367. Natural Resources Canada, Canadian Forest Service, Pacific Forestry Centre, Victoria. 37 p

Sharma BD, Sidhu PS, Nayyar VK (1992) Distribution of micronutrients in arid zone soils of Punjab and their relation with soil properties. Arid Soil Res Rehabil 6:233-242

Silversides C (1997) Broadaxe to flying shear: the mechanization of forest harvesting east of the Rockies. National Museum of Science and Technology, Ottawa. $174 \mathrm{p}$
Simmons FC (1949) Since the days of Leif Ericson. In: Stefferud A (ed) Trees: the yearbook of agriculture. U.S. Department of Agriculture, Washington, DC, pp 697-694

Smith RS, Shiel RS, Bardgett RD et al (2003) Soil microbial community, fertility, vegetation, and diversity as targets in the restoration management of a meadow grassland. J Appl Ecol 40:51-64

Society for Ecological Restoration [SER] International Science and Policy Working Group [SER] (2004) The SER international primer on ecological restoration. Available at http://www.ser.org/. Accessed 10 Apr 2019

Society for Range Management [SRM] Glossary Update Task Group (1998) Glossary of terms used in range management, 4th edition. Available at https://globalrangelands.org/glossary/

Society for Range Management [SRM] Task Group on Unity in Concepts and Terminology Committee Members (1995) New concepts for assessment of rangeland condition. J Range Manag 48:271-282

Solaiman ZM, Murphy DV, Abbott LK (2012) Biochars influence seed germination and early growth of seedlings. Plant Soil 353(1-2):273-287

Sosa-Pérez G, MacDonald LH (2017) Effects of closed roads, traffic, and road decommissioning on infiltration and sediment production: a comparative study using rainfall simulations. Catena 159:93-105

Spears JD, Holub SM, Harmon ME, Lajtha K (2003) The influence of decomposing logs on soil biology and nutrient cycling in an oldgrowth mixed coniferous forest in Oregon, USA. Can J For Res 33(11):2193-2201

Stanturf JA, Palik BJ, Dumroese RK (2014) Contemporary forest restoration: a review emphasizing function. For Ecol Manag 331:292-323

Stone DM (2002) Logging options to minimize soil disturbance in the northern Lake States. North J Appl For 19(3):115-121

Stott DE, Martin JP (1989) Organic matter decomposition and retention in arid soils. Arid Soil Res Rehabil 3:115-148

Strayer D, Glitzenstein JS, Jones CG et al (1986) Long-term ecological studies: an illustrated account of their design, operation, and importance to ecology. Institute of Ecosystem Studies, Millbrock, pp $1-38$

Sun G, Zhang L, Duan K, Rau B (2017) Impacts of forest biomass removal on water yield across the United States. In: Efroymson RA, Langholtz MH, Johnson KE, Stokes BJ (eds) Billion-ton report: advancing domestic resources for a thriving bioeconomy, volume 2 -environmental sustainability effects of select scenarios from volume 1. Oak Ridge National Laboratory, Oak Ridge. 640 p

Surface Mining Control and Reclamation Act; Act of August 3, 1977; 30 U.S.C. 1201 et seq

Swetnam TW, Allen CD, Betancourt JL (1999) Applied historical ecology: using the past to manage for the future. Ecol Appl 9:1189-1206

Switalski T, Bissonette J, DeLuca TH et al (2004) Benefits and impacts of road removal. Front Ecol Environ 2(1):21-28

Taylor AG, Harman GE (1990) Concepts and technologies of selected seed treatments. Annu Rev Phytopathol 28(1):321-339

Thibodeau L, Raymond P, Camiré C, Munson AD (2000) Impact of precommercial thinning in balsam fir stands on soil nitrogen dynamics, microbial biomass, decomposition, and foliar nutrition. Can J For Res 30:229-238

Thomas P, Packham J (2007) Ecology of woodlands and forests: description, dynamics, and diversity. Cambridge University Press, Cambridge. $481 \mathrm{p}$

Tongway DJ, Valentin C, Seghieri J (eds) (2001) Banded vegetation patterning in arid and semiarid environments: ecological processes and consequences for management. Springer-Verlag, New York

U.S. Department of Agriculture, Forest Service [USDA FS] (2012) Forest service manual, FSM 250 watershed and air management, chapter 2550 soil management, R9 supplement. U.S. Department of Agriculture, Northeast Region, Milwaukie 
U.S. Department of Agriculture [USDA] (2003) National Range and Pasture Handbook. U.S. Department of Agriculture, Natural Resources Conservation Service, Grazing Lands Technology Institute, Washington, DC. $214 \mathrm{p}$

U.S. Department of Agriculture, Forest Service [USDA FS] (2010) Forest Service Manual, FSM 2500 watershed and air management, chapter 2550 soil management. WO amendment 25002010-1. U.S. Department of Agriculture, National Headquarters, Washington, DC

U.S. Department of Agriculture, Forest Service [USDA FS] (2017) Fiscal year 2018 budget justification. U.S. Department of Agriculture, Washington, DC. $319 \mathrm{p}$

U.S. Department of Agriculture, Forest Service [USDA FS] (2018) Colville National Forest land management plan (Ferry, Pend Oreille, and Steven Counties, Washington). U.S. Department of Agriculture, Pacific Northwest Region, Portland

U.S. Department of the Interior [US DOI] (2015) Rangeland fire prevention, management, and restoration. Secretary order number 3336. U.S. Department of the Interior, Washington, DC. http://www.forestsandrangelands.gov/rangeland/documents/ SecretarialOrder3336.pdf

U.S. Department of the Interior, Bureau of Land Management [BLM] (2017) Budget justifications and performance information, fiscal year 2018. U.S. Department of the Interior, Washington, DC. $446 \mathrm{p}$

U.S. Government (2014) United States of America spending. Available at http://www.usaspending.gov/

Vallejo R, Serrasolses I, Alloza JA et al (2009) Long-term restoration strategies and techniques. In: Fire effects on soils and restoration strategies. Science Publishers, Enfield, pp 373-398

Van Zwieten L, Kimber S, Morris S et al (2010) Effects of biochar from slow pyrolysis of papermill waste on agronomic performance and soil fertility. Plant Soil 327:235-246

von Wilpert K, Schäffer J (2006) Ecological effects of soil compaction and initial recovery dynamics: a preliminary study. Eur J For Res 125:129-138

Walton M (2005) Spatial patterning of resource accumulation in a 22 year-old water harvesting project in the Chihuahuan Desert. University of Dayton, $\mathrm{PhD}$ dissertation, Dayton, $\mathrm{OH}$

Walton M, Herrick JE, Gibbens RP, Remmenga M (2001) Persistence of biosolids in a Chihuahuan Desert rangeland 18 years after application. Arid Land Res Manag 15:223-232

Wang J, LeDoux CB, Edwards P, Jones M (2005) Soil bulk density changes caused by mechanized harvesting: a case study in central Appalachia. For Prod J 55(11):37-40
Wertz WA, Arnold JF (1972) Land systems inventory. U.S. Department of Agriculture, Forest Service, Ogden. $12 \mathrm{p}$

Westoby M, Walker B, Noy-Meir I (1989) Opportunistic management for rangelands not at equilibrium. J Range Manag 42(4):266-274

Wiens JA (1984) The place for long-term studies in ornithology. Auk 101:202-203

Wiens JA (1986) Spatial scale and temporal variation in studies of shrubsteppe birds. In: Diamond J, Case TJ (eds) Community ecology. Harper and Row, New York, pp 154-172

Wiens JA (1989) Spatial scaling in ecology. Funct Ecol 3(4):385-397

Wilde SA (1958) Forest soils. The Ronald Press Company, New York. $537 \mathrm{p}$

Wilkinson BH (2005) Humans as geologic agents: a deep-time perspective. Geology 33:161-164

Williams M (1989) Americans and their forests: a historical geography. Cambridge University Press, Cambridge. $624 \mathrm{p}$

Williams MI, Paige GB, Thurow TL et al (2011) Songbird relationships to shrub-steppe ecological site characteristics. Rangel Ecol Manag 64(2):109-118

Williams CJ, Pierson FB, Spaeth KE et al (2016a) Application of ecological site information to transformative changes on Great Basin sagebrush rangelands. Rangelands 38(6):379-388

Williams MI, Dumroese RK, Page-Dumroese DS, Hardegree SP (2016b) Can biochar be used as a seed coating to improve native plant germination and growth in arid conditions? J Arid Environ $125: 8-15$

Williamson JR, Neilsen WA (2000) The influence of forest site on rate and extent of soil compaction and profile disturbance of skid trails during ground-based harvesting. Can J For Res 30:1196-1205

Wubs ERJ, van der Putten WH, Bosch M, Bezemer TM (2016) Soil inoculation steers restoration of terrestrial ecosystems. Nat Plants 2(8): 16107

Wyoming Department of Environmental Quality (1996) Coal rules and regulations. Wyoming Department of Environmental Quality, Land Quality Division, Cheyenne. Chapter 4

Young KE, Grover HS, Bowker MA (2016) Altering biocrusts for an altered climate. New Phytol 210:18-22

Zhang J, Busse MD, Young DH et al (2017) Aboveground biomass responses to organic matter removal, soil compaction, and competing vegetation control on 20-year mixed conifer plantations in California. For Ecol Manag 401:341-353

Zhu AX (2000) Mapping soil landscape as spatial continua: the neural network approach. Water Resour Res 36(3):663-677

Open Access This chapter is licensed under the terms of the Creative Commons Attribution 4.0 International License (http://creativecommons. org/licenses/by/4.0/), which permits use, sharing, adaptation, distribution and reproduction in any medium or format, as long as you give appropriate credit to the original author(s) and the source, provide a link to the Creative Commons license and indicate if changes were made.

The images or other third party material in this chapter are included in the chapter's Creative Commons license, unless indicated otherwise in a credit line to the material. If material is not included in the chapter's Creative Commons license and your intended use is not permitted by statutory regulation or exceeds the permitted use, you will need to obtain permission directly from the copyright holder. 